\title{
LA IMPORTANCIA DEL AGUA: EL ARROYO DEL SALADO DE CAULINA EN EL TÉRMINO MUNICIPAL DE JEREZ DE LA FRONTERA Y EL RÍO IRO EN EL TÉRMINO MUNICIPAL DE CHICLANA DE LA FRONTERA
}

\author{
THE ROLE OF THE WATER: THE SALADO DE CAULINA STREAM IN THE MUNICIPAL AREA \\ OF JEREZ AND THE IRO RIVER IN THE MUNICIPAL AREA OF CHICLANA
}

\section{Raquel MARTÍNEZ ROMERO}

Doctora en Historia y Arqueología Marítima

Correo electrónico: raquelmr2007@hotmail.com

\begin{abstract}
Resumen: A lo largo de estas páginas se presentan los diversos yacimientos arqueológicos desde cronologías de la Prehistoria hasta la Edad Media, asociados tanto al cauce del Arroyo del Salado de Caulina en el Término Municipal de Jerez de la Frontera como al del río Iro en el Término Municipal de Chiclana de la Frontera. Para así, poder abordar la posible hipótesis (surgida durante el trabajo de Tesis Doctoral de la autora), de unificación entre ambas vías fluviales en época Calcolítica, concretamente en la transición del IV al III milenio a.n.e., mediante el uso de mapas geoarqueológicos y el análisis del topónimo "Salado". Concluyendo con una aproximación de las diversas actividades productivas de las sociedades clasistas iniciales gaditanas asociadas al elemento agua.
\end{abstract}

Palabras Clave: Arroyo del Salado de Caulina, río Iro, Calcolítico, la importancia del agua, la sal, Término Municipal de Jerez de la Frontera, Término Municipal de Chiclana de la Frontera.

\begin{abstract}
Throughout these pages I introduce the various archaeological sites from Prehistoric times to the Middle Ages associated to the course of both the Salado de Caulina stream in the municipal área of Jerez and the Iro river in the municipaity of Chiclana, in order to tackle the hypothesis (removed in the subject of my doctoral studies) of the posible unification of both waterways in the Chalcolithic period - in particular in the transition between the fourth and third millennium B.C.-, by means of the use of geo-archaeological maps and the analysis of the place name "Salado". Finally, we shall approach different productive activities of the early clasist societies in Cádiz concerning the water element.
\end{abstract}

Keywords: The Salado de Caulina stream, the Iro river, Chalcolithic, the rol of the water, the salt, Jerez Region, Chiclana Region.

Sumario: 1. Introducción. 2. El Arroyo del Salado de Caulina. 3. El río Iro. 4. ¿Coincidencia de nombres, una única vía fluvial u otra cosa? 5. Conclusiones. 6. Bibliografía.

\section{Introducción}

Dicho tema surge de la tesis doctoral "Estudio comparativo de los modos de vida de las sociedades de la Prehistoria Reciente (milenios IV - III a.n.e.) a través de los productos líticos hallados de zonas litorales, marismas y campiñas de Jerez y Bahía de Cádiz: El Trobal y La Esparragosa" donde observamos la importancia del agua, elemento primordial en cuanto a la supervivencia y al control del territorio.

En el tránsito del IV al III milenio a.n.e. en la actual provincia de Cádiz se desarrollaron poblados adscritos a la cultura de los silos. Estos enclaves presentaban un amplio control del territorio, al localizarse en plataformas elevadas desde donde se divisaba el territorio colindante, además de estar próximos a cursos de agua. Asimismo, en cuanto a la estructuración espacial del yacimiento, se componían de zonas de hábitat y de silos, estructuras negativas para el excedente agrícola, incluyendo algunos una zona de enterramiento y de lugar de producción del material lítico.

En la actualidad conocemos que la cultura de los silos, bautizada así por Collantes de Terán (1969), 
es un fenómeno que se distribuye por todo el Guadalquivir y por áreas de Extremadura y Portugal, asociado a sociedades agrícolas-ganaderas y con el surgimiento de los primeros estados prístinos en el suroeste de Andalucía, especialmente entre Sevilla y Cádiz con Valencina de la Concepción. Además de una cultura material conformada por herramientas líticas talladas con reminiscencias de periodos epipaleolíticos (Martínez, 2021) y por cerámica.

Y es en todo este contexto donde el río Iro y el Arroyo del Salado de Caulina tienen un papel principal pues articulan el territorio desde la sierra de Gibalbín hasta Chiclana. Por ello en un primer lugar, vamos a analizar los distintos yacimientos arqueológicos cercanos al cauce, para así poder conocer la relación que existió entre ambos en época calcolítica, momento donde las comunicaciones tenían un gran peso debido al surgimiento de los primeros estados prístinos.

\section{El Arroyo del Salado de Caulina}

Dicho arroyo, enmarcado en el T.M. de Jerez de la Frontera, ha sido ampliamente citado en las fuentes documentales antiguas, aunque con otras denominaciones como Badalejo, Badalac, Badalae, Salado de Cuenca, Albadalejo... (Abellán, 2002; Cuadrado, 2007, 2011a, 2011b; Guevara, 1539; Gutiérrez, 1755; López y Zarzana, 1787; Martín, 2004; Portillo, 1839) y por tanto, diversos episodios históricos se encuentran estrechamente ligados a él.

Nace en la sierra de Gibalbín, exactamente en Fuente del Rey, y drena un amplio territorio conformado por la sierra de Gibalbín, los Llanos de Caulina y la margen derecha del río Guadalete, con una cuenca de 23.000 hectáreas y una longitud de unos 23,5 km entre los arroyos tributarios de su cabecera y su curso principal. Además de presentar múltiples afluentes como los arroyos de Santiago, de El Chivo, de Canillas, Arroyodulce, del Gato, del Rano o del Cuadrejón y de la Canaleja (Plano 1).

La sierra de Gibalbín, con una altura de $412 \mathrm{~m}$ y actualmente parcialmente degradada, presenta materiales triásicos con restos de cobertera plegada encima, formando parte de la tectónica del Subbético. Además de los abanicos aluviales originados por la sedimentación de la carga proveniente de diversas corrientes fluviales, dando lugar a la laguna de Tollos. Dicha zona ha tenido un gran valor estratégico desde la Prehistoria al estar rodeada de las llanuras del Guadalete y del Guadalquivir.
Continuando el curso del arroyo nos encontramos con los Llanos de Caulina, dicho territorio fue unión entre los valles del Guadalete y Guadalquivir hasta hace unos 2M de años (González y Ruiz, 1999), cuando pliegues y fallas levantaron el terreno al norte de los Llanos, creando así la actual divisoria de las cuencas de ambos ríos y eliminando dicha conexión. De esta manera, se convirtió la zona en una depresión conectada con el estuario del Guadalete teniendo el aspecto de un gran estero y de un extenso aguazal con multitud de canales (Gutiérrez Mas et al., 1991).

Finalmente dicho arroyo confluye en el río Guadalete, lugar de múltiples inundaciones en la actualidad hasta que se realizaron las obras de restauración ambiental en 2011. Dichas obras consistieron en la restitución de la sección hidráulica, despejando las riberas cegadas por eucaliptos, además de retirar una gran cantidad de sedimentos y ensanchándolo en su margen derecha en su unión con el Guadalete (Fonseca, 2011; García, 2011) (Figura 1).

Debido a dichas obras se ha podido recuperar la vegetación autóctona conformada por álamos, tarajes y sauces, pudiéndose así reparar el aspecto de los sotos fluviales (Figura 1).

Pero el arroyo del Salado no es sólo importante por su recorrido navegable por pequeñas embarcaciones hasta mediados del siglo XX, sino también por los distintos yacimientos arqueológicos encontrados en sus márgenes, ejemplos de la importancia de la zona a lo largo de la historia.

La primera zona con presencia arqueológica es la propia Sierra de Gibalbín (Plano 1, no 1), que debió de estar habitada desde épocas prehistóricas en sus cuevas, aunque los primeros hallazgos en la zona se relacionan con dos escarabeos en plata o esteatita vidriada de factura egipcia o fenicia y fechados en los siglos VIII-VI a.C. Posteriormente, se documentó un diploma militar con inscripción en bronce correspondiente a la licencia de un pretoriano de la Cohorte X Pretoria del año 166 d.C. haciendo referencia a época romana (Caballero, 2019; González, 2014), además en sus aledaños se han descubierto cuatro villas romanas con cronologías desde el siglo I al VII d.C. En época musulmana se construye un castillo almohade debido al valor estratégico en el sistema defensivo de la zona que tuvo dicha sierra y ya tras la Reconquista ostentará un papel destacado entre 1274 y 1284 con las múltiples razzias realizadas por los benimerines en la comarca jerezana (García, 2008). 

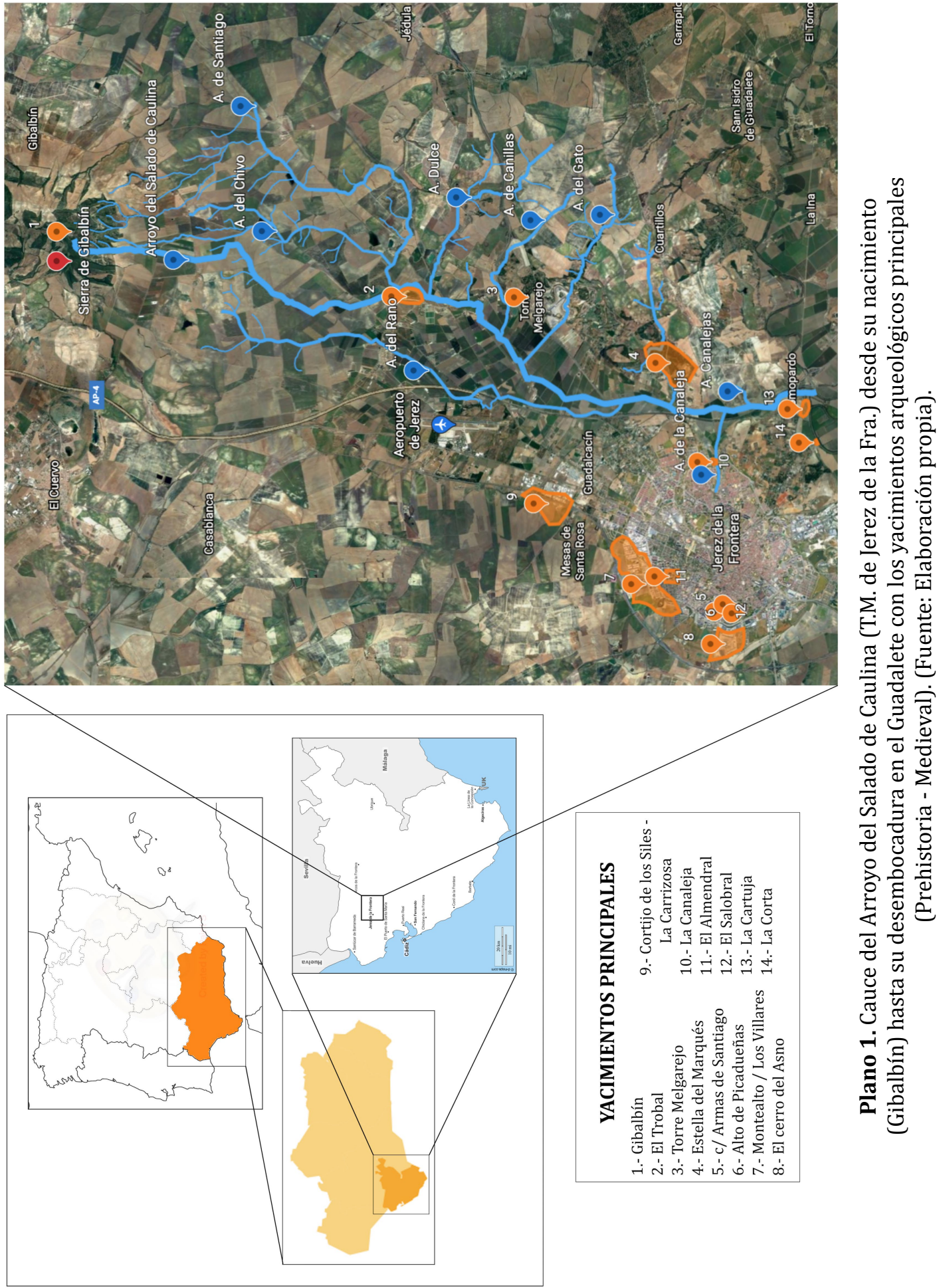

Revista Atlántica-Mediterránea de Prehistoria y Arqueología Social 23, pp. 43-71 


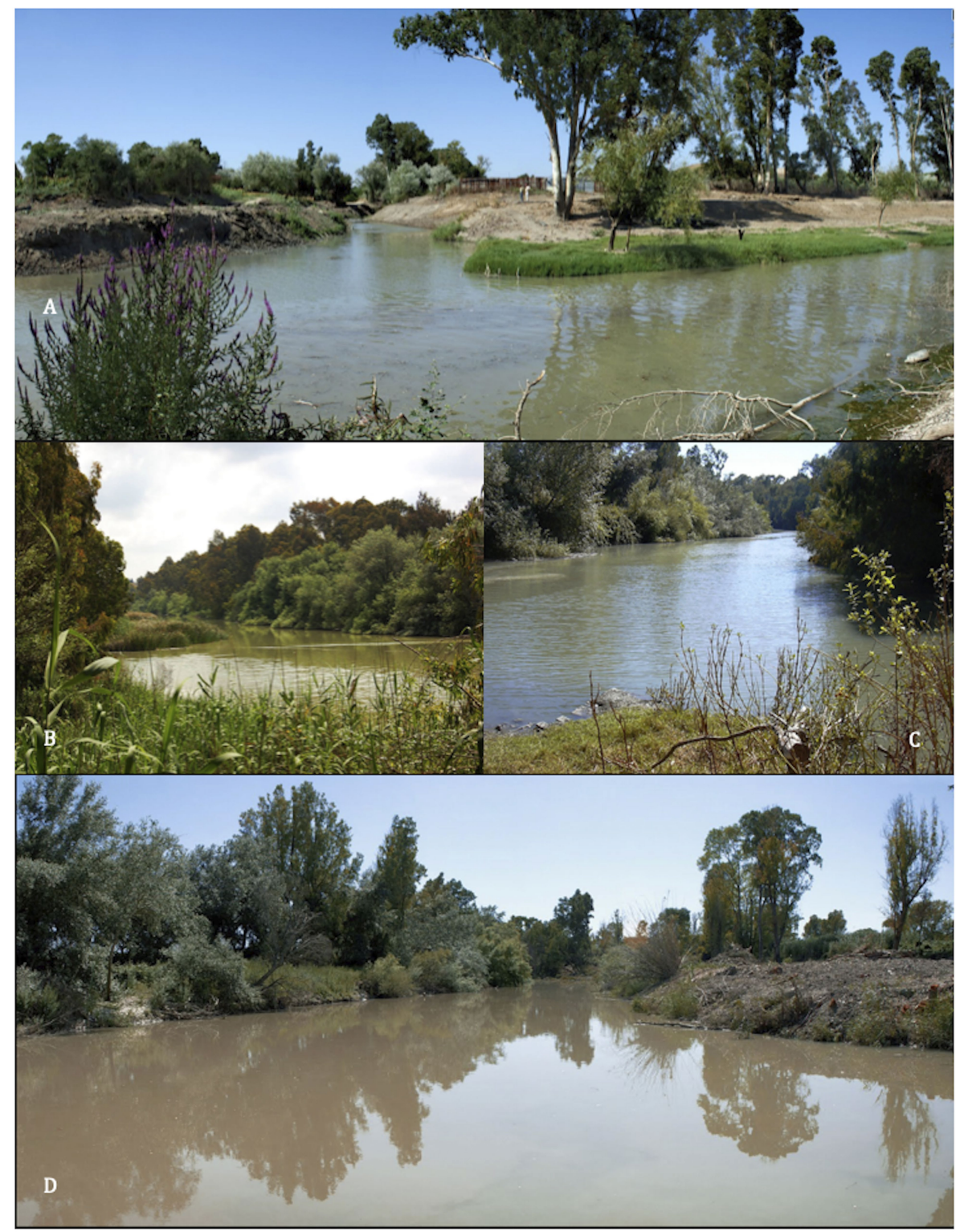

Figura 1. Fotografías de ambos márgenes del Arroyo del Salado de Caulina. A y D. Margen izquierda, a la espalda de los viveros, donde se puede observar gran cantidad de sedimentos, grandes árboles, escombros y obstáculos. B y C. Margen derecha donde se han realizado las obras de restauración ambiental en 2011 y donde se puede observar la vegetación autóctona de tarajes y sauces. (Fuente: García y García, 2011).

No será ya hasta los Llanos de Caulina donde nos encontremos con el yacimiento de El Trobal (Figura 2; Plano 1, no 2), cuyas cronologías abarcan desde el IV milenio a.n.e. hasta la Edad del Cobre. Fue excavado entre 1984 y 1988 bajo la dirección de Rosalía González Rodríguez (1987a), y en la actualidad sólo presenta un amplio cerro de unos 50 m.s.n.m. entre los arroyos de La Basurta y La Jarilla, afluentes del Arroyo del Salado, debido a la presencia de una cantera de extracción de áridos que provocó tanto su descubrimiento como su desaparición

El poblado de El Trobal debió de ser un impor- tante enclave pues a lo largo de las cuatro campañas arqueológicas se constató una distribución del espacio en distintas zonas (Figura 2): una de hábitat con la presencia de dos fondos de cabaña, un sector destinado a la acumulación de excedentes agrícolas por la cantidad de silos documentados (casi un centenar), además de enterramientos en algunos de ellos y por último, una superficie destinada para la producción de las herramientas líticas denominada "taller" por los arqueólogos que lo excavaron.

Además, durante los años de excavación se documentaron un total de 109 silos, entre los que se en- 


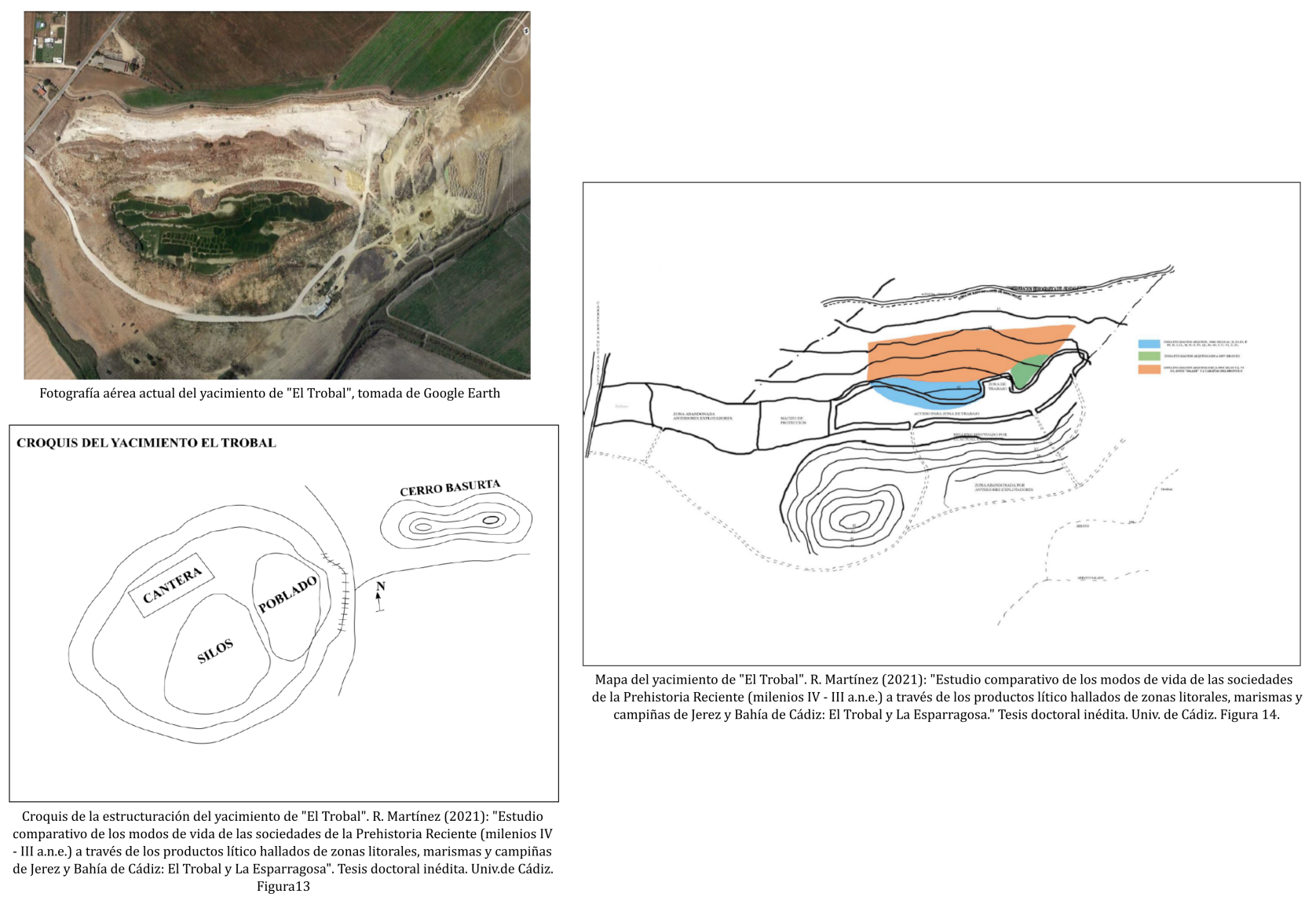

Figura 2. Visión aérea, estructuración y distribución espacial del yacimiento de "El Trobal" (Jerez de la Frontera). (Fuente: Elaboración propia).

contraron cuatro enterramientos cuyo estudio antropológico fue llevado a cabo por Ruiz et al. (1991). Estas estructuras negativas se concentraban en grupos de 10, 8, 6 y 4 silos y algunos se encontraban colmatados por piedras calizas de gran tamaño. También se realizaron varias prospecciones, tanto de la zona de la cantera en la ladera Este, como de cerros colindantes a ella: La Basurta y el Cortijo de El Trobal, donde se encontraron abundantes restos cerámicos correspondientes al siglo II y III d.C. posiblemente relacionados con varias villas romanas. Y por último, se analizaron dos cabañas del Bronce Final, cuyo estudio fue realizado mediante cuadrantes llegándose a la conclusión de que los materiales encontrados, un total de 130, se localizaban "in situ" y tenían una ocupación monofásica en momentos avanzados del Bronce Final Orientalizante (González y Ramos, 1991; Ramos, 1991).

En cuanto al material arqueológico documentado se realizó una primera aproximación general en 1987 (González, 1987), si bien es cierto que se centra en los materiales cerámicos divididos entre formas carenadas con un predominio de las cazuelas, no carenadas con vasos de cuerpos esféricos y paredes verticales, con ollas globulares y algunos cuencos y platos de gran diámetro y por último, otras formas cerámicas como fragmentos de cucharas y cucharones de arcilla, embudos y "crecientes" o "cuernecillos" de arcilla con perforaciones en los extremos. Además de tratar los motivos decorativos como cordones, mamelones, pintura almagra, superficies bruñidas, la técnica incisa y fragmentos pintados con motivos geométricos: zigzag, bandas horizontales, líneas verticales...

En relación a la lítica, contamos a día de hoy con el artículo de José Ramos Muñoz (1991) y la tesis doctoral de dicha autora (2021). El primero trata sobre el material documentado dentro de los dos fondos de cabaña del Bronce Final, mientras que el segundo realiza un estudio de todo el material lítico, tallado y pulimentado, encontrado tanto en las estructuras negativas como en la zona denominada "taller". Así pues se ha podido comprobar que dicho enclave cuenta con una cronología que va desde el tránsito del Neolítico Final al Calcolítico, debido a la presencia de productos de tradición epipaleolítica, láminas con retoques continuos, hojas estrechas propias del Neolítico, además de 
elementos de hoz, foliáceos, una amplia diversidad de núcleos y ejemplares sobre lascas con un plano de golpeo, elementos característicos del Calcolítico (Figura 3).

$\mathrm{Y}$ en cuanto a estudios de otras disciplinas, disponemos del estudio antropológico de Ruiz et al. (1991), que concluía que la mayoría de los individuos pertenecían al tipo mediterráneo grácil, a excepción de un individuo con rasgos del tipo mediterráneo robusto y otros dos con rasgos alpinoides. También sugiere que el conjunto "se aproxima a poblaciones coetáneas en el tiempo como El Argar y Neo-eneolíticas de Levante, situándose más próximas de los primeros" (Botella et al., 1991: 46).

Y el análisis de los restos malacológicos (Figura 4) realizado por J.J. Cantillo Duarte (2013) observándose, por un lado, una destacada presencia del bivalvo Ruditapes decussatus, y por otro, un balance de las prácticas económicas en relación al consumo de moluscos como complemento de la caza y/o recolección. Además de información de tipo paleoambiental, pues la zona en estas cronologías se correspondía a una inmensa bahía interna con un nivel del mar bajo, desarrollándose un paleoambiente dominado por medios costeros restringidos tipo estuarios y playas arenosas poco expuestas.
Poco más podemos saber de dicho yacimiento, pues la falta de estudios específicos y la pérdida de información documental provocan vacíos científicos, no por ello, se va a dejar de investigar dicho enclave e intentar su puesta en valor, estando en proceso la realización de un monográfico a partir del conocimiento obtenido con la tesis doctoral.

El siguiente enclave que nos encontramos a lo largo del curso de este arroyo, se encuentra situado en la población de Torre Melgarejo (Plano 1 no 3). En dicha población ya en 1956 M. Esteve Guerrero aprecia restos arqueológicos, exactamente una vasija de la Edad del Bronce Mediterráneo, además de hachas de piedras y sepulturas sin mayor documentación (Esteve, 1956, 1962). Posteriormente en 1986 se realiza una entrega de material arqueológico, posiblemente el ajuar de un enterramiento, al Museo Arqueológico de Jerez de la Frontera fruto de obras de cimentación de unas casas de la zona alta del pueblo realizadas en los años 70 .

En 1988 se documenta la excavación de un sepulcro de inhumación colectiva (Figura 5), que presentó forma de tendencia abovedada y base plana sin recubrimiento interior de unos $1,30 \mathrm{~m}$ de altura y 2,60 $\mathrm{m}$ de diámetro. Se desconocía la entrada al haber sido afectada por el talud de la

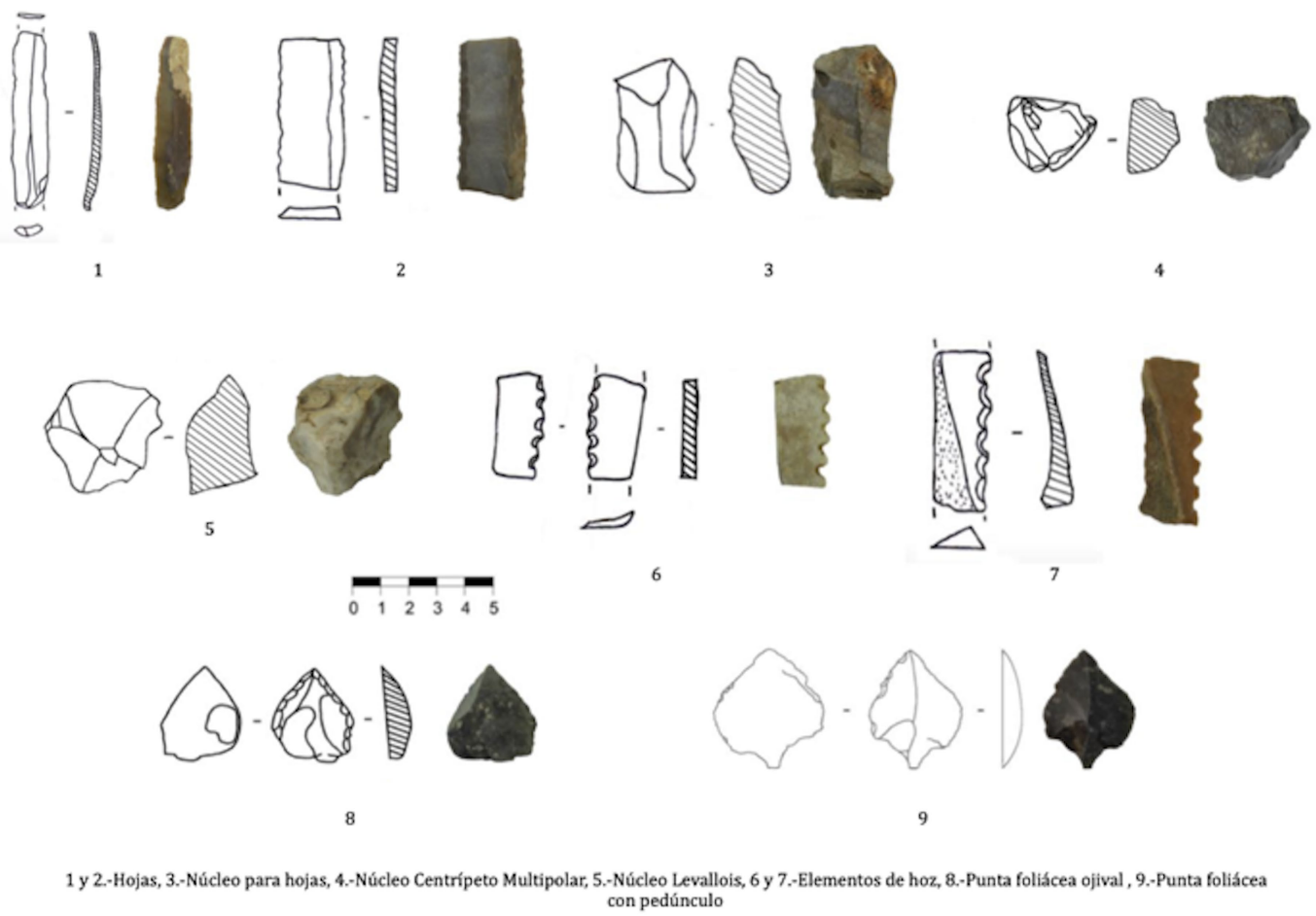

Figura 3. Material lítico perteneciente al yacimiento de "El Trobal”. (Fuente: Martínez, 2021). 
La importancia del agua: el Arroyo del Salado de Caulina en el Término Municipal de Jerez de la Frontera y el río Iro en el Término Municipal de Chiclana de la Frontera

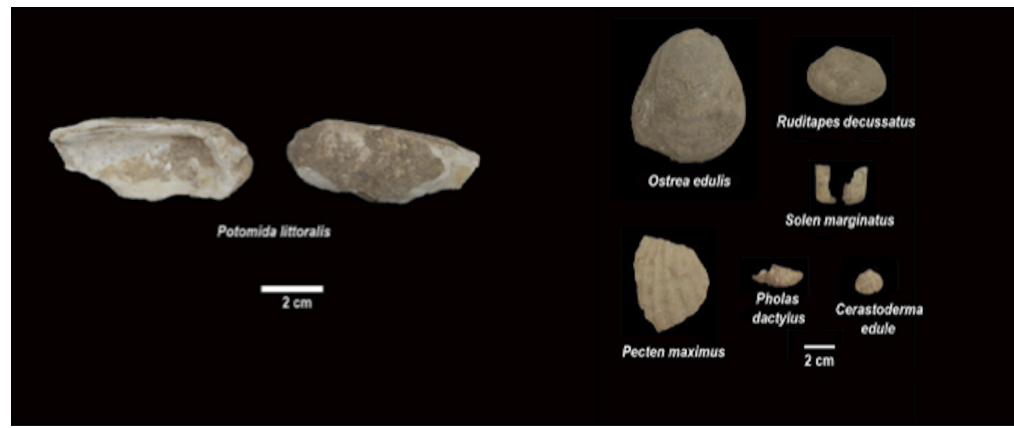

Figura 4. Material malacológico perteneciente al yacimiento de "El Trobal". (Fuente: Cantillo, 2013).

antigua carretera Jerez-Arcos y por labores de desmonte. Por sus características se asoció al tipo silo o cueva artificial de cámara simple con entrada central o lateral. El conjunto de los huesos, perteneciente a once individuos, se concentraba en la parte central y oriental, mientras que el ajuar se disponía siguiendo la línea de la pared en el arco Sur y Oeste.

Entre el ajuar se documentaron once vasos cerámicos, una alabarda de sílex (Figura 5) (Ramos, 2014-15, 2017), un total de doce productos líticos tallados entre los que destacan seis puntas foliáceas de aletas desarrolladas y un disco pulimentado, dos pequeños cuencos cerámicos, un fragmento de punzón de cobre y siete conchas Zonaria pyrum y Conus mediterraneus perforadas mediante percusión directa que debían formar parte de un collar (Figura 5) (Cantillo, 2019). Además de un fragmento correspondiente al extremo de un punzón metálico.

Dicho enterramiento se encuadra en torno a fines del III e inicios del II milenio a.n.e. Según sus investigadores, dicho enterramiento no es usual que aparezca aislado por lo que apuntan hacia un amplio complejo Calcolítico, situado en torno al actual poblado de Torre Melgarejo, basándose también en las anteriores apariciones de material en el poblado.

Por último, anotar que la existencia de objetos de prestigio: la alabarda de sílex, las puntas foliáceas de aletas desarrolladas (Figura 5) o el collar de conchas, nos hace pensar en una posible diferenciación social debido a un proceso de jerarquización social reflejado en el ajuar de los individuos de estas sociedades, donde las élites locales de territorios de la periferia presentan productos de lujo y prestigio en relación a una clara tendencia militarista y con evidencias claras de "conflicto".

Pero Torre Melgarejo no sólo se relaciona con sociedades clasistas iniciales del III-II milenio a.n.e., sino también con época romana, destacando el yacimiento de Cerro Naranja (Carretero, 2004 González, 1987b, 1987c; González y Ruiz, 1999), y con época medieval debido al Castillo (figura 6). En la actualidad, aunque se encuentra catalogado como Bien de Interés Cultura (BIC) desde 1985, presenta un estado de total abandono y cerrado a las visitas, además de sufrir en agosto de 2018 el desplome de una parte de los muros de la esquina oeste del muro perimetral.

Dicho castillo se relaciona con el sistema defensivo que integraba un buen número de torres y atalayas en la zona para el control de las inestables fronteras con los reinos musulmanes. Y debido a documentación antigua, expresamente a un testamento de 1391 de Catalina Martínez, se conoce ya la existencia de dicha torre perteneciente a la familia Martínez de Cuenca. Posteriormente con otro testamento, el del jurado Pedro Díaz Melgarejo, nieto de la anterior, de 1466 se tiene conocimiento del cambio de nombre de dicha torre, pasando a denominarse Torre de Diego Díaz (Moreno, 2018).

Continuando con nuestro recorrido, nos encontramos a la altura de Estella de Marqués, creado entre 1954-1967 como pueblo de colonización agrícola para poner en regadío las tierras y cubrir el despoblado existente entre el sector oriental del término de Jerez y la serranía gaditana (Gómez, 2012). En dicho municipio nos encontramos con un yacimiento romano (Plano $1, \mathrm{n}^{-}$4) conocido desde 1980 con la realización de prospecciones arqueológicas que determinaron la existencia de un núcleo industrial de producción alfarera del s. I d.C. con abundancia de ánforas vinarias asociado a una villa de producción, que tenía salida por la gran laguna que formaba el arroyo (objeto de este artículo) para la exportación a Roma y a otra zonas del imperio.

$\mathrm{Y}$ al otro margen nos encontramos con lo que a día de hoy es la ciudad de Jerez (González et al., 

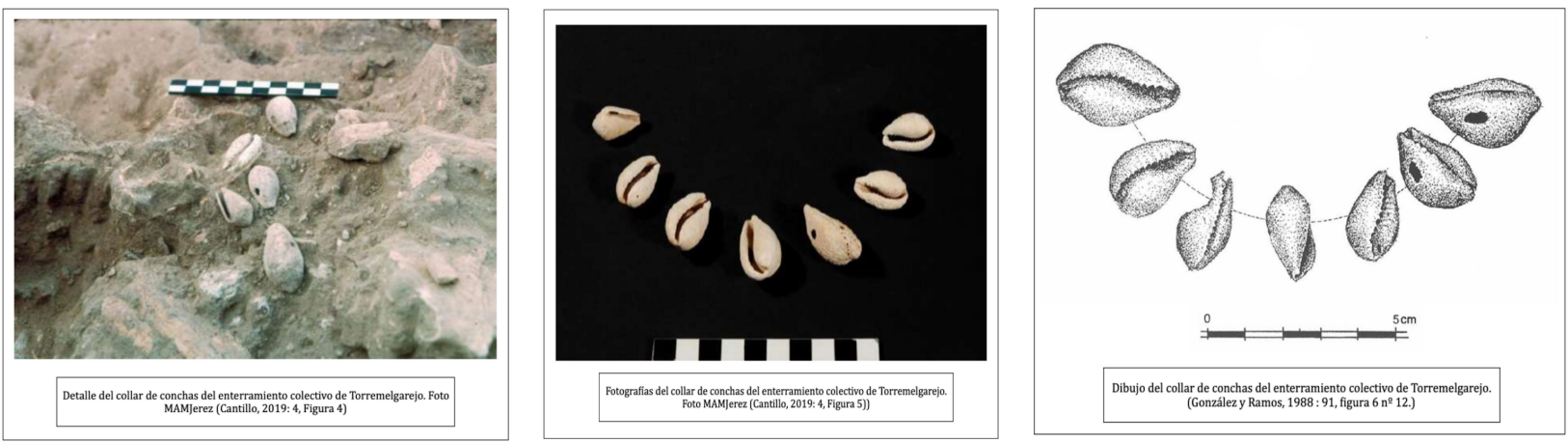

(4)
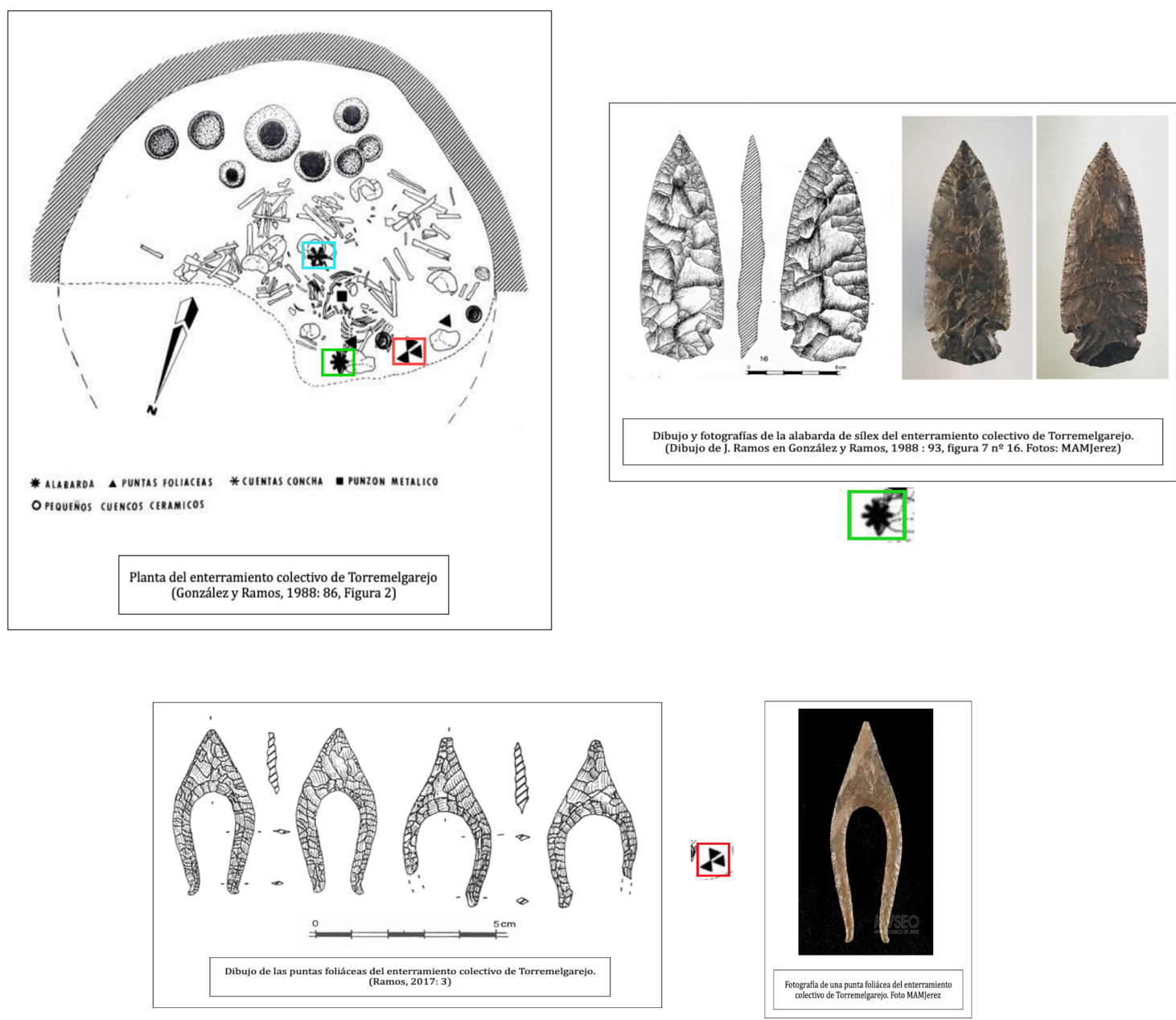

Figura 5. Enterramiento colectivo de Torremelgarejo: distribución y objetos de prestigio.

(Fuente: Elaboración propia). 


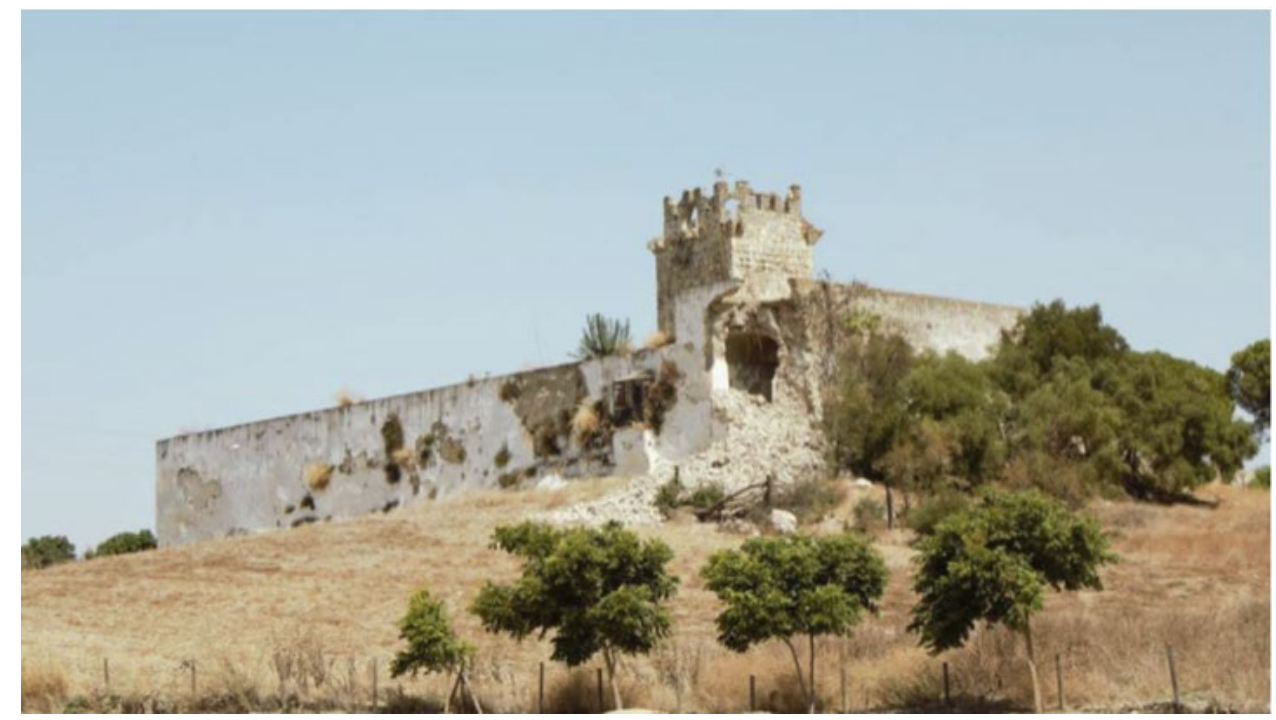

Figura 6. Fotografía del castillo medieval de Torremelgarejo. (Fuente: Cañas, 2018).

2008) aunque se encuentra un poco alejado del curso del río, esta zona tiene presencia homínida desde el IV-III milenio a.n.e. con los yacimientos de calle Armas de Santiago, alto de Picadueñas, Montealto-Los Villares, el cerro del Asno y Cortijo de los Síles-la Carrizosa, todos ellos encuadrados dentro de la cultura de los silos. La presencia de restos no es demasiado abundante, a excepción del yacimiento de Cortijo de los Siles - la Carrizosa que aporta material metálico con un estoque en Bronce y del yacimiento del alto de Picadueñas, con presencia de fondos o cubetas, agujeros de postes de cabañas o empalizadas, además de material cerámico, lítico y óseo debido a la presencia de enterramientos (Plano 1, no 5 - 9).

El enclave relacionado con época protohistórica cercano al cauce del Arroyo se constata de nuevo en Montealto-Los Villares (González et al., 2008; López, 2007 y 2009) (Plano 1, no 7) perteneciente al siglo VI a.C. fechado por un arínbalo corintio, además de documentarse ánforas, cerámicas grises y platos y lucernas de engobe rojo.

A lo largo de época romana y antigüedad tardía, la arqueología muestra establecimientos dedicados a la producción anfórica, vinculados a explotaciones particulares y podría relacionarse con el espacio denominado "ager ceretanus" de Columela (Álvarez, 1824). Así pues se ha constatado la presencia de alfares en La Canaleja (Plano 1 no 10), en Montealto - Los Villares (Plano 1, no 7), en El Almendral y en El Salobral (Plano 1, no 11 y 12). Se estima que la fecha general de todos ellos sean los siglos I y II d.C., aunque el yacimiento de Montealto - Los Villa- res podría haber perdurado hasta el Bajo Imperio.

Ya será a partir de época islámica prealmohade cuando se configure el inicio de la actual ciudad de Jerez, del cual no vamos a tratar, ya que sería necesario otro artículo para explicar toda la evolución acaecida.

Finalmente en la desembocadura del Arroyo del Salado nos encontramos con el último yacimiento ligado directamente con el curso de este, el enclave de La Cartuja (Plano 1, no 13), donde se ubica una villa romana junto al monasterio. Muy relacionada a ella estaría el complejo de molinos (Figura 7) localizado junto al antiguo azud de la Corta (Plano $1, \mathrm{n}$ - 14), donde se localizaron un molino romano, otro islámico con estructura abovedada y otro medieval, manteniéndose estos ingenios hasta el s.XVIII, aunque sin un uso sincrónico (Limón, 2019; Sánchez, 2016). Además de restos de una cárcel y de un embarcadero o dique romano.

Retomando la villa romana de La Cartuja se conoce que estuvo situada en la sala denominada "Habitación vieja", exactamente en el Patio de la Obediencia, antiguo Sotillo, debido a un mosaico que apareció en unas obras realizadas en el s. XX el cual fue dibujado por Escalera, localizados en el Archivo de la Cartuja y posteriormente cubierto para albergar los edificios destinados a las labores domésticas (Castellano, 2017; González et al., 2008).

\section{El río Iro}

Para entender el origen de dicho río debemos 


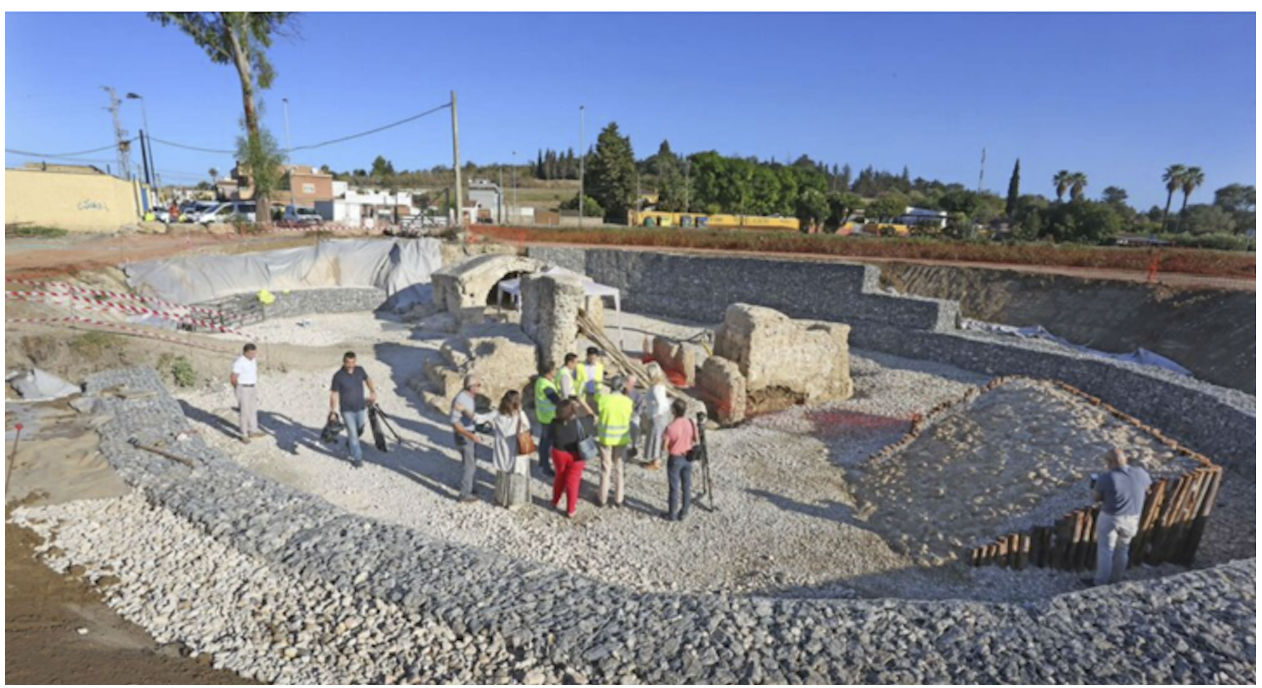

Figura 7. Complejo de molinos localizados en La Corta (Jerez de la Frontera). (Fuente: Pascual, 2019).

analizar primero su etimología. Aunque todavía está por resolver, en fuentes antiguas aparece denominado como Tiro o Siro, en la Edad Media como Besilo (Galava, 1992; Romero, 2015), y posteriormente, desde el s. XVII, Lirio, Liro o Iro.

Aunque la derivación de Besilo a Iro no es fácil, su evolución podría responder a la desaparición de la primera sílaba "Bes-", dándose el cambio de "-ilo" a Iro. Además, en cuanto al significado, Bessignifica "agua, corriente o río", mientras que -ilo se refiere al tipo de caudal: "rugiente, tumultuoso, espumoso", y teniendo en cuenta que la palabra Iro, de raíz indoeuropea, significa exactamente lo mismo (enérgico e impetuoso), sería la evolución más lógica (Grupo Iro XXI, 2016a, 2016b).

En cuanto al primer hidrónimo de Tiro o Siro, $\mathrm{y}$ teniendo en cuenta la presencia fenicia en la zona con el yacimiento arqueológico del "Cerro del Castillo", se cree que el nombre provendría de la ciudad de Tiro, aunque esta hipótesis apenas tiene fundamento, derivando posteriormente hacia Siro, Liro o Iro (Autrán, 1898; Grupo Iro XXI, 2016a, 2016b).

Por último, se podría asociar dicha nomenclatura a la diosa Iris, diosa griega, debido a que las personas que hacían encargos o transmitían mensajes eran llamadas de dicha manera en época griega y entiendo que, a través del río, se hubiera realizado algún tipo de transporte vinculado a los sacerdotes del templo del Herakleio, con el que los romanos preservaron el culto al Herakles griego y al Melqart fenicio (Paredes, 1985).

Por otra parte, la cuenca del río Iro es la más extensa del T.M. de Chiclana de la Frontera, por ello numerosos arroyos confluyen en él. A la altura del cementerio mancomunado, se produce una bifurcación entre el Arroyo Salado hasta llegar al embalse del Pedroso con diferentes afluentes (Arroyo del Palmetín, Arroyo del Impío, Arroyo de las Salinillas, Arroyo del Toro, Arroyo del Saltillo, Arroyo de Valsequillo, Arroyo del Cañuelo, Arroyo de la Cepa, Arroyo de los Gamuzones, Arroyo Amarguillo y Arroyo de la Carriona) y el Arroyo de la Cueva con los siguientes afluentes: Arroyo de Pozo Blanco, Arroyo de Cabeza de Vaca, Arroyo de los Pilones, Arroyo de Galindo, Arroyo de la Zahúrda, Arroyo de Rabanete, Arroyo del Lentiscar, Arroyo de los Majadles.... (Plano 2). Entre sus características se encuentra la presencia de aguas salinas debido al influjo de las mareas que se adentran aproximadamente unos $6 \mathrm{kms}$, siguiendo el cauce del río (Bohórquez, 1996).

En relación a su conformación se puede apreciar fangos y vegetación marismeña como sapinas y almajos, hasta el final del meandro frente a la urbanización La Carabina, donde la vegetación de los márgenes presenta nuevas especies como carrizos y tarajes, además de fauna: garzas, garcetas, patos azulones, martinetes, martín pescador o pollas de agua. También en un tramo del Arroyo Salado (Figura 8) se vislumbran pies de acebuches, que recuerdan al bosque primigenio, entre arbustos como lentiscos y palmitos y en menor medida tomillo, alcauciles silvestres, espárragos y tagarninas, entre los que habitan conejos y perdices (Grupo Iro XXI, 2017).

Por último, mientras que el Arroyo Salado se comporta como un torrente estacional: en verano 


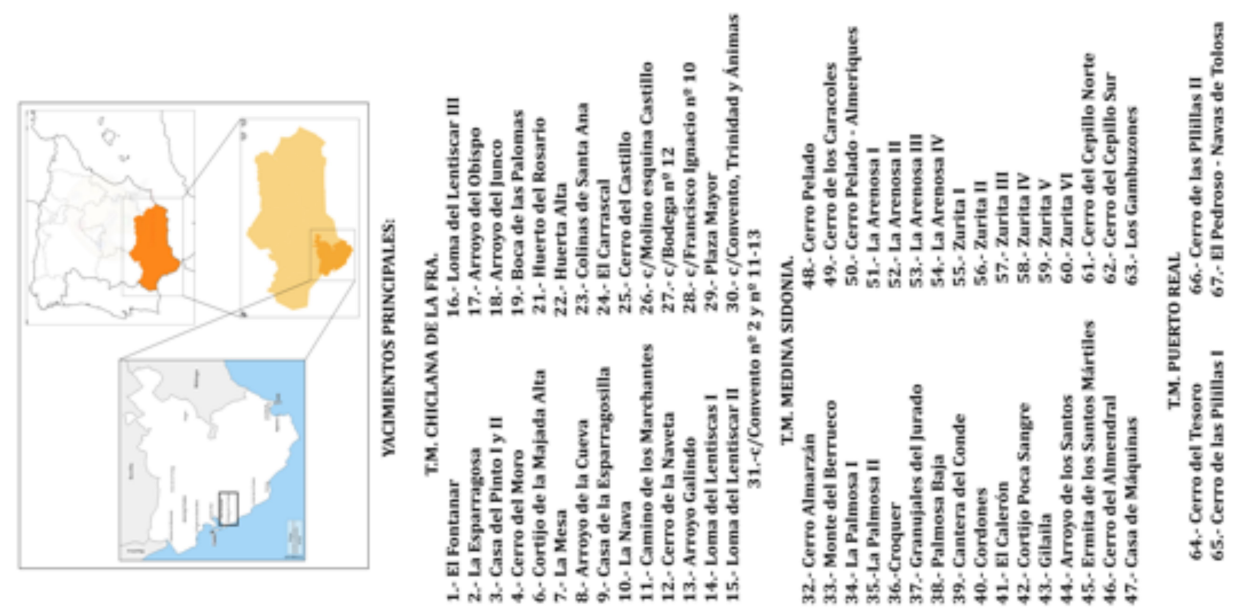

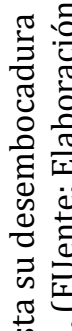

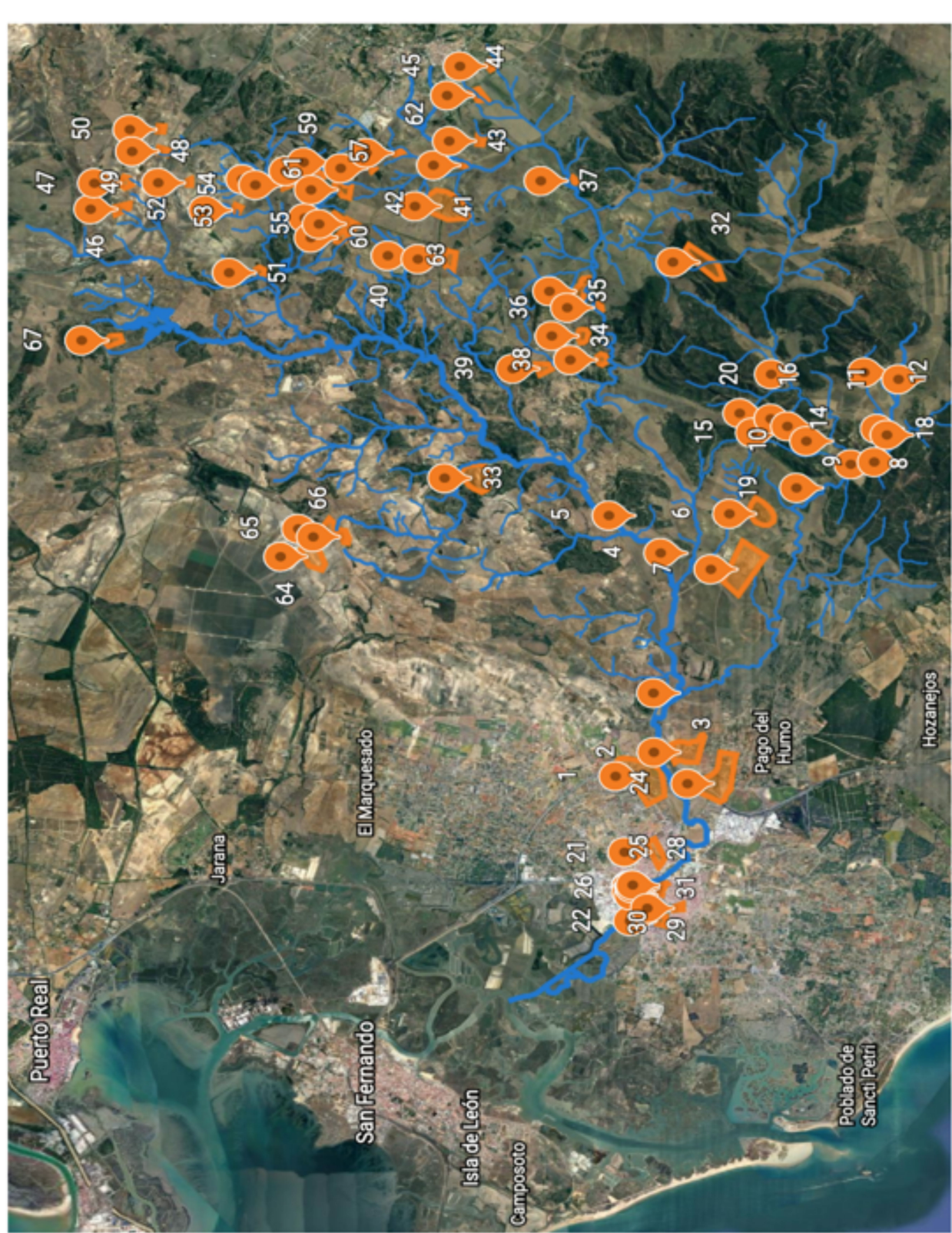

के

옹

일

ป

$\overline{\mathrm{d}}$

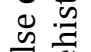

$\frac{\pi}{\square}$

这范

유ㄹㅠㅠ

焉

ते

赵

के $\cdot{ }^{\circ}$

a

递

$\frac{0}{2} \stackrel{0}{=}$

$\pi$

흐 :

$\breve{\breve{c}}$

ป

它

$\sum^{i} \pi$

$\sum_{i}^{\infty} \approx$

용

을 을

$\frac{E_{0}}{0}$

o

氖

త్

ก

응

츤

Revista Atlántica-Mediterránea de Prehistoria y Arqueología Social 23, pp. 43-71 
tiene un caudal discontinuo con charcas aisladas y con la mayoría de los afluentes menores secos, aunque aporta el $60 \%$ del caudal; el Arroyo de la Cueva, contribuyendo sólo con el 40\%, presenta agua a lo largo de todo el año debido a que en la parte final recoge aguas de terrenos con cerros y mayor pendiente que en sus primeros $9 \mathrm{~km}$ con terrenos de muy poca pendiente, además del aporte del arroyo de la Salinilla (Grupo Iro XXI, 2017).

Desde un principio, el río Iro se ha considerado como un canal de navegación, pero anteriormente, remontándonos a época prehistórica, hace unos 300.000 años aproximadamente, antepasados paleolíticos ya lo frecuentaban.

La zona del Arroyo de la Cueva presenta una composición geológica lacustre donde tuvo que destacar la importancia paleoambiental aprovechada por las comunidades de cazadores-recolectores como fuente de recursos hídricos y faunísticos. En ella se reconocen cuatro niveles de aterrazamientos escalonados en donde se han localizado yacimientos arqueológicos a nivel superficial, lo que indica una ocupación humana con motivaciones estratégico-defensivas (cerros, hombreras en situación prominente y fuentes de recursos) posterior al desarrollo del sistema de terrazas (Plano 2, no 6 - 20) (Grupo Iro XXI, 2016c).

De hecho se ha realizado un Modelo Digital Te- rrestre por parte del Seminario Agustín Horozco de la Universidad de Cádiz (2014) (Figura 9) el cual nos facilita entender como era el río Iro en la Prehistoria y en la Antigüedad, así se conoce que su desembocadura se localizaba en las proximidades del Cerro del Castillo y de la Iglesia de San Sebastián-Pico del Oro, teniendo en cuenta que la línea de costa no era la actual, sino mucho más hacia el interior, "recortando la ladera noroeste del cerro, formando una especie de cabo. Hacia el interior, vertiente arriba, aparece un amplio cauce y una especie de pequeña albufera lo que nos permite comprender que fuera navegable hasta las proximidades de Medina Sidonia" (Bueno, 2015). Todo ello, constatado arqueológicamente, en las obras de la Avenida de Reyes Católicos de 2009 con niveles de arena de playa y antropizados de época Bronce Final y fenicia, además de época tardorromana.

Pero retomando momentos del Paleolítico Inferior, debemos hablar de los yacimientos de La Mesa (Plano 2, no 7) que presenta una diacronía hasta momentos del II milenio a.n.e. y que detallaremos más adelante, Camino de los Marchantes I y II (Plano 2, no 11), Cortijo Majada Alta (Plano 2, no 6), Arroyo del Obispo (Plano, 2 no 17), Arroyo del Junco (Plano 2 , no 18) y Boca de las Palomas (Plano 2, no 19), localizándose sólo el yacimiento Arroyo de la Cueva (Plano 2, no 8) para cronologías de Paleolítico Medio.

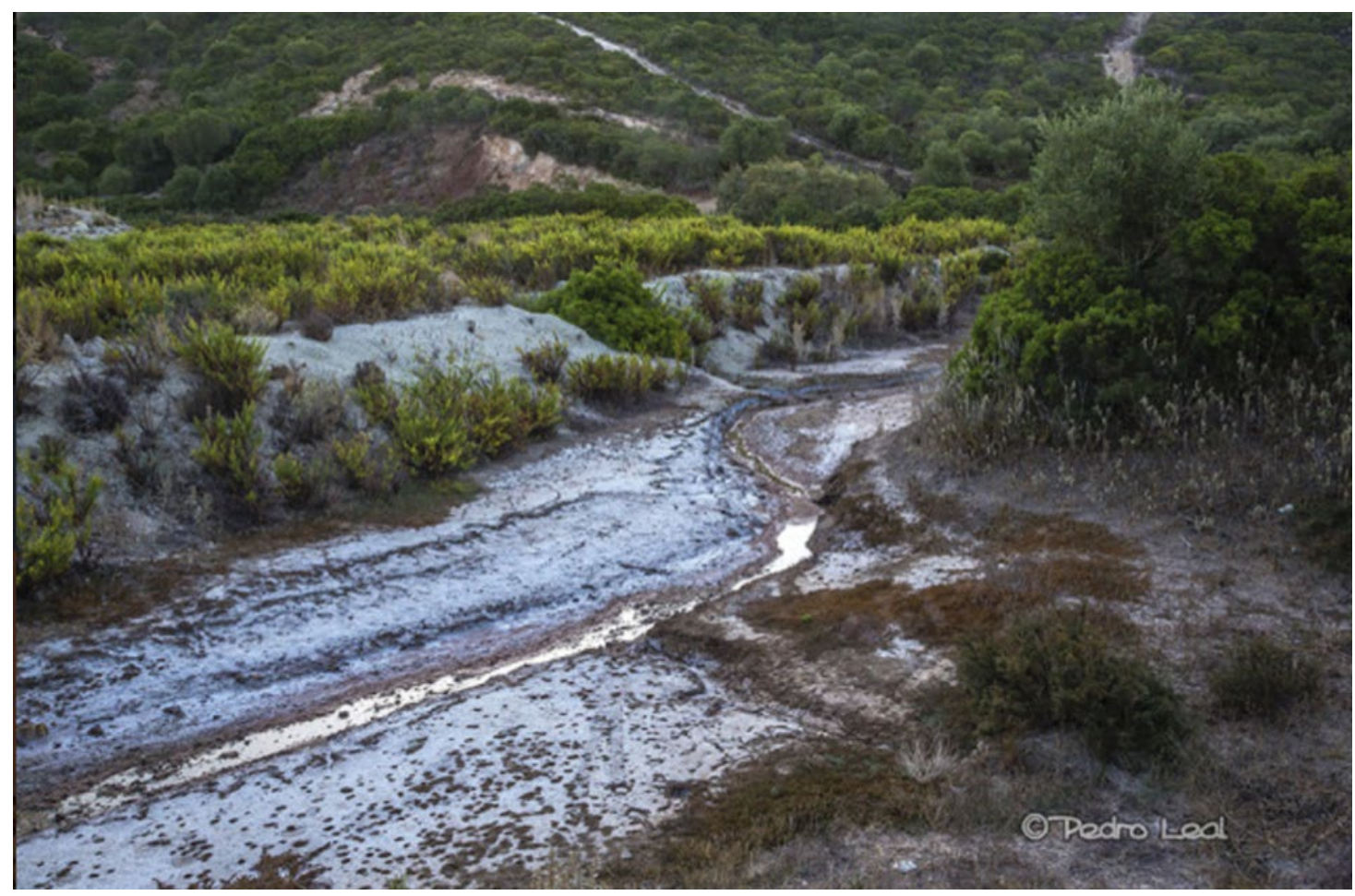

Figura 8. Cauce del Arroyo Salado (Chiclana de la Frontera, Cádiz). (Fuente: http://grupoiroxxi.blogspot. com/2017/10/la-cuenca-alta-del-iro-el-arroyo-salado.html). 
La importancia del agua: el Arroyo del Salado de Caulina en el Término Municipal de Jerez de la Frontera y el río Iro en el Término Municipal de Chiclana de la Frontera

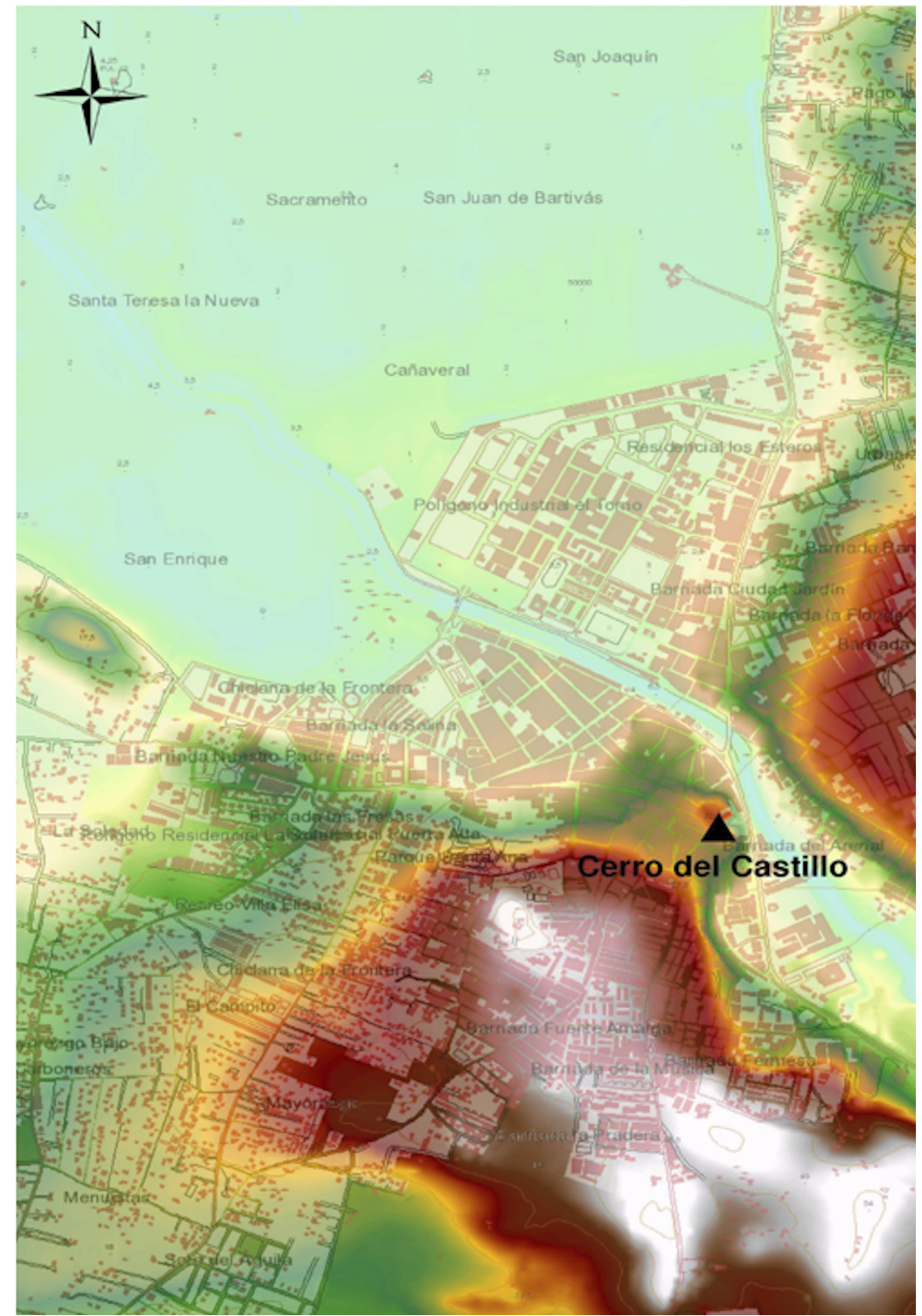

Figura 9. Modelo Digital Terrestre. Seminario Agustín Horozco de la Universidad de Cádiz.

(Fuente: Bueno, 2018: 8 fig. 2).

En relación a época Neolítica debemos hablar según cronologías. Para el V - IV milenio a.n.e. asociado al tránsito hacia sociedades tribales, los emplazamientos presentan dimensiones reducidas sobre plataformas elevadas con un modo de producción agropecuario junto a recursos costeros. De este modo, se pueden asociar a dicho momento los yacimientos arqueológicos de La Mesa (Plano 2, no 7), Arroyo de la Cueva (Plano 2, no 8), Arroyo Galindo (Plano 2, no 13), Casa de la Esparragosilla (Plano 2, no 9), El Fontanar (Plano 2, no 1) y La Esparragosa (Plano 2, no 2). En todos ellos se puede observar la perduración del sustrato de tradición neolítica y paleolítica tanto en productos líticos como cerámicos.
El enclave de La Esparragosa (Figura 10; Plano 2, no 2) ha sido ampliamente estudiado con las cuatro campañas de excavaciones llevadas a cabo, recogidas tanto en el libro monográfico de Vijande et al. (2019) como en la tesis doctoral de la autora de este artículo, leída en 2021, a las cuales nos remitimos para un mayor conocimiento del mismo.

Para el III milenio a.n.e., momentos donde se produce la consolidación de las sociedades tribales y se inicia el tránsito hacia sociedades clasistas iniciales, aumenta el número de enclaves: La Mesa (Plano 2, no 7), Cerro del Moro (Plano 2, no 4), Camino de los Marchantes I y II (Plano 2, no 11), La Nava (Plano 2, no 10), Cortijo Majada Alta (Plano 2, no 6), Casa de la Esparragosilla (Plano 2, no 9), 
Cerro de la Naveta (Plano 2, no 12), Cerro de la Angostura (Plano 2, no 20), Loma del Lentiscar I y II (Plano 2, no 14 y 15) y el Fontanar (Plano 2, no 1).

Como se puede apreciar, localizaciones como La Mesa, Casa de la Esparragosilla o El Fontanar surgen en momentos anteriores presentando una diacronía a lo largo de todo el momento Neolítico, incluso en cronologías posteriores como es el caso de La Mesa o de Cortijo Majada Alta

Finalmente, asociados al II milenio a.n.e. tenemos, de nuevo, La Mesa, además de Cortijo Majada Alta, Casa de la Esparragosilla, Loma del Lentiscar I a III (Plano 2, no 14 a 16) y Casa del Pinto I y II (Plano 2, no 3).

Como podemos apreciar algunos enclaves presentan una diacronía histórica como son los casos de La Mesa, Camino de los Marchantes I y II, Casa de la Esparragosilla, Loma del Lentiscar I-II o el Fontanar.

El yacimiento de La Mesa, localizado en plena campiña litoral, exactamente a $7 \mathrm{~km}$ del casco urbano de Chiclana hacia el este, se conoce desde 1993 gracias a las prospecciones que se realizaron dentro del proyecto de investigación "Las ocupaciones prehistóricas de la campiña litoral y banda atlántica de Cádiz" a cargo del Dr. José Ramos Muñoz.

La primera excavación se realizó en otoño de 1998 dentro del proyecto de investigación "Estudios de las formaciones económicas y sociales prehistóricas de la banda atlántica de Cádiz", también dirigido por el Dr. José Ramos Muñoz.

Su ubicación, en una colina amesetada de 50 m de altitud y de 1200m x 700 m (Figura 11), y su proximidad a vías de comunicación: el río Iro y la cañada de los Marchantes hacen de ella un sitio idóneo para el asentamiento de nuestros antepasados desde el Paleolítico Inferior hasta el siglo XIII.

En época prehistórica, dicho yacimiento destaca durante el IV milenio a.n.e., siendo especialmente significativo en el III y II milenio a.n.e. al organizar y controlar el territorio Oeste de la campiña de Cádiz: producción, sitios de extracción y aprovechamiento de materias primas vinculadas a la producción agrícola, control del territorio..., debido a una red de asentamientos sincrónicos. Así pues en la Edad del Bronce el control territorial se organizaría en base a La Mesa, El Berrueco y Medina Sidonia, mientras que en el Bronce Final pa-

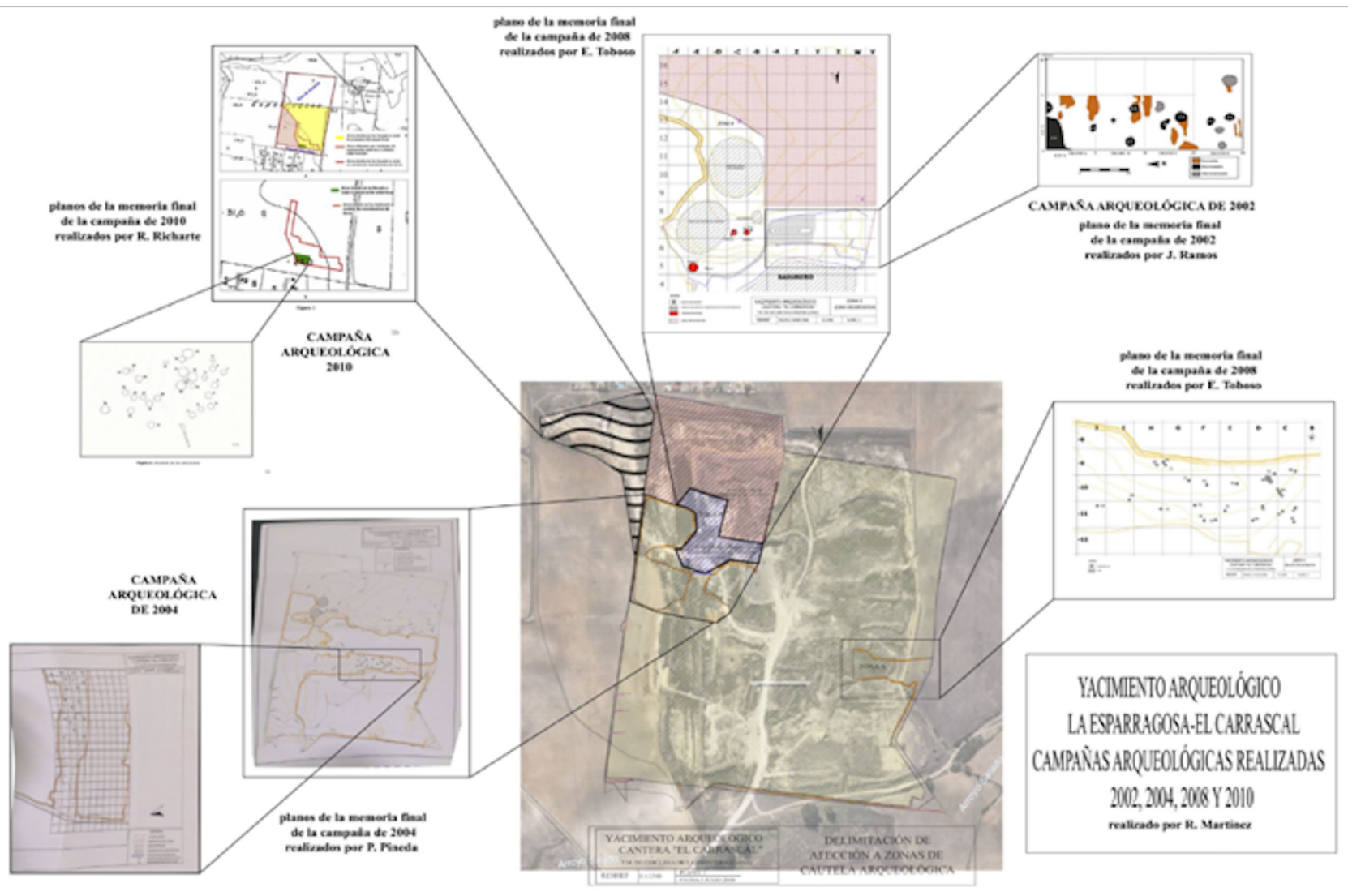

Figura 10. Campañas arqueológicas del yacimiento de La Esparragosa. (Fuente: Martínez, 2021). 


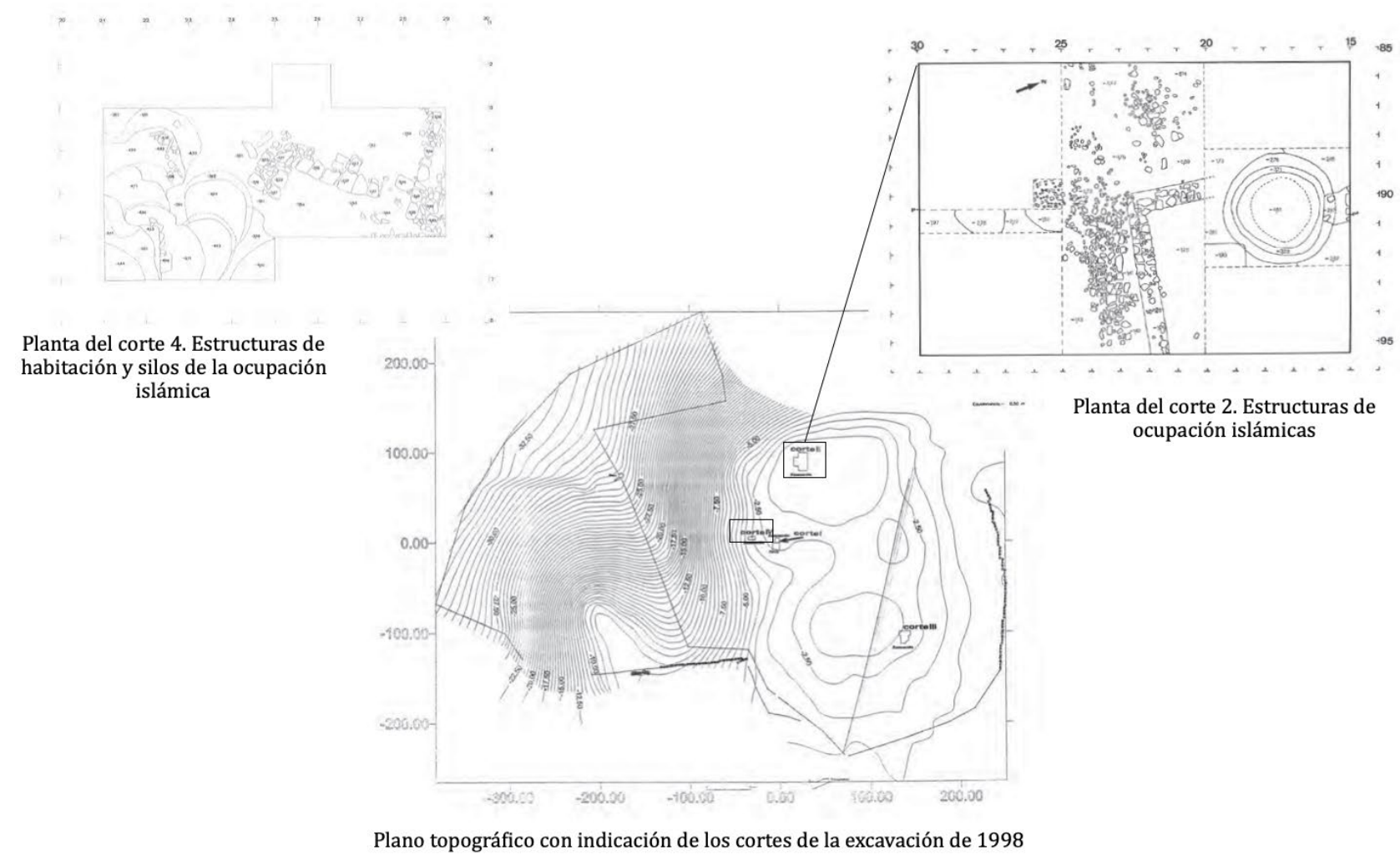

Figura 11. Planos de las excavaciones realizadas en el yacimiento de La Mesa (Chiclana de la Frontera) en 1998. (Fuente: Ramos et al., 1998).

saría a ocupar un lugar marginal en la ordenación territorial, dependiente de los otros dos poblados, pues tanto El Berrueco como Medina Sidonia desarrollarán relaciones comerciales entre los grupos de poder indígenas y la comunidad fenicia.

En cuanto a su organización interna, presentaba un sistema de amurallamiento, localizándose dentro una gran concentración de materiales prehistóricos desde el Calcolítico hasta Edad del Bronce. Dicho material refleja la perduración de la caza junto a actividades agrícolas y ganaderas con importantes restos de cerámicas de utillaje doméstico.

Pero la zona no sólo presenta momentos prehistóricos sino que también debemos hacer referencia a la villa romana de época imperial localizada en la zona NE de más de $500 \mathrm{~m} 2$ y posteriormente a diferentes momentos: en primer lugar época emiral, un segundo de tradición taifa con producciones del siglo XI, y un último post-almohade relacionado con cerámica nasríes de finales del siglo XIII.

Continuando el desarrollo cronológico del poblamiento del T.M. de Chiclana de la Frontera, nos encontramos con diferentes enclaves dentro de la propia ciudad como son el caso del yacimiento del Cerro del Castillo (Plano 2, no 25), c/Molino esquina Castillo (Plano 2, no 26), c/Francisco Ignacio 10 (Plano 2, no 28), c/Convento-Santísima Trinidad-Ánimas (Plano 2, no 30) y c/Convento 2 (plano 2, no 31).

El enclave de Cerro del Castillo (Figura 12) presenta un poblado de Bronce Final - Hierro I, posiblemente del siglo VIII a.n.e., debido a su carácter estratégico al ser un promontorio que controlaba el paso del río Iro, en el lugar más angosto y cercano a la costa, con una vaguada a su alrededor y dándole la forma de cabezo exento. De dicha época sólo ha quedado presencia de las ánforas tipo pithoi, las jarritas para aceites y perfumes o las pequeñas botellitas de pasta vítrea. En cuanto a los restos constructivos se localizó una recia y potente muralla de casernas, típico de una fortificación con doble muro paralelos separados por muros transversales, de tipología oriental, relacionados con momentos tartésicos, turdetanos y fenicios. En su interior se han conservado las cimentaciones de las viviendas y almacenes y los suelos de arcilla apisonada (Bueno, 2014, 2018, 2021).

Si bien en la c/Molino esquina Castillo no se documentaron estructuras constructivas, sí se constata la presencia humana desde el siglo VIII a.n.e. 


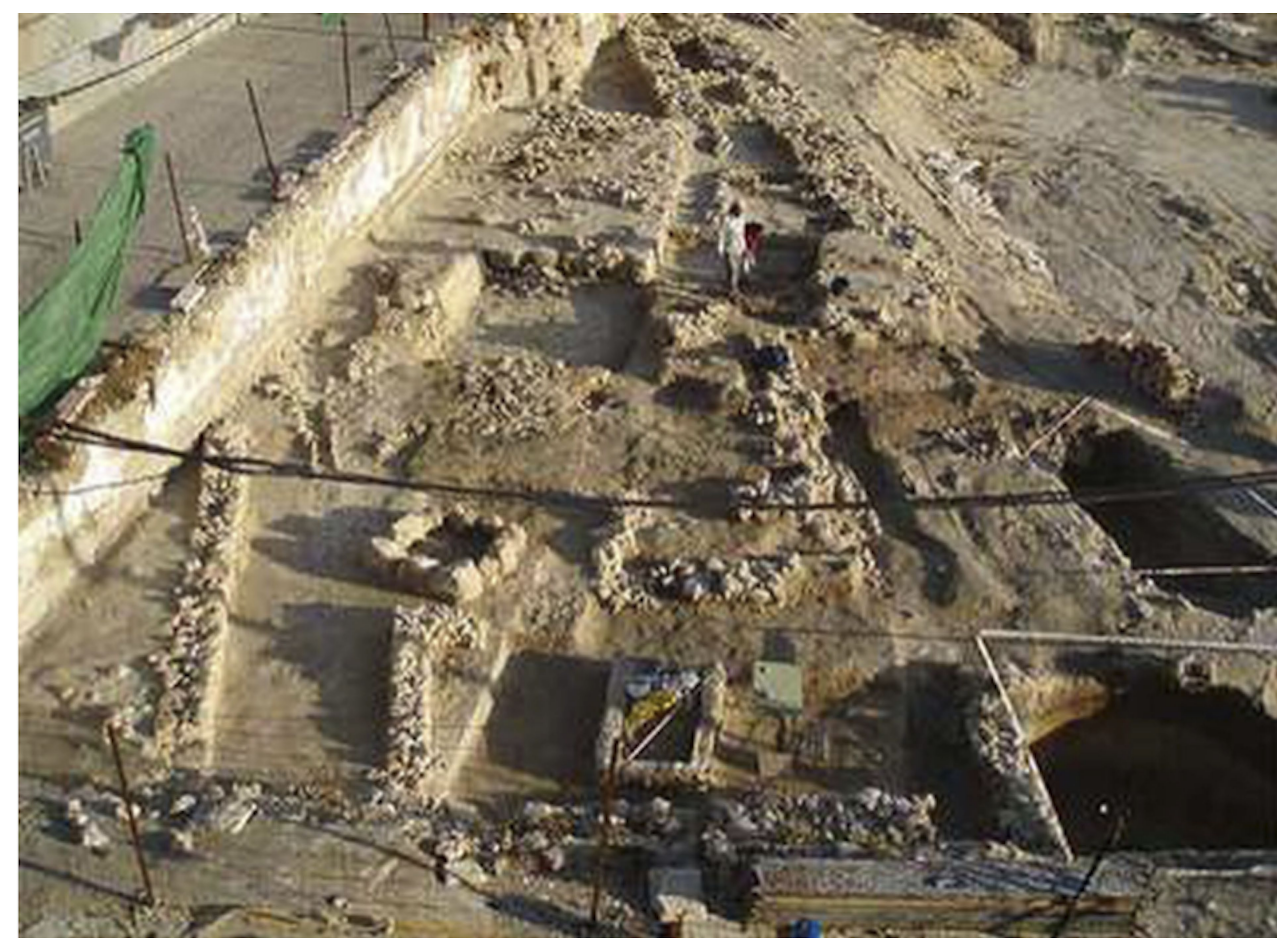

Figura 12. Vista aérea del yacimiento Cerro del Castillo (Chiclana de la Frontera). (Fuente: https://elpais.com/diario/2008/06/23/andalucia/1214173330 850215.html).

y en los siglos V-IV a.n.e., muy relacionado con los restos del horno, posiblemente de pan, hallado en el solar colindante. Todo ello permite ubicar con exactitud el perímetro que ocupó la ciudad fenicia, además del asentamiento de Prehistoria Reciente.

En relación a la época fenicia (s. VII-VI a.C.), el solar de c/Francisco Ignacio no 10 documentó la presencia de una zona de hábitat con tres grandes estancias delimitadas por unidades murarias y de forma regular, tanto cuadrada como rectangular, ambas con suelos de cal y pequeños fragmentos de cerámica. Por desgracia, no se conocen ni los límites ni la funcionalidad, aunque se localizaron restos artefactuales adscribibles tanto a época fenicia como a época turdetana. A dicha cronología hay que sumarle los hallazgos de las diferentes actividades arqueológicas de las calles Convento Santísima Trinidad - Ánimas, donde se documentó una muralla de casernas formada por dos lienzos de muros paralelos unidos cada cierto tramo por una serie de muros transversales, idéntica a la de Cerro del Castillo, que rodeaba todas las estancias halladas: viviendas, recintos domésticos y un horno de pan y un fogón. Por último, otro horno fue localizado en la c/Convento 2 adscrito a época turdetana (s. VI-V a.C.) del que sólo quedaba el fondo (Bueno, 2014, 2015, 2018, 2021).

$\mathrm{Y}$ en cuanto al siglo $\mathrm{V}$ a.C. tenemos constancia de estructuras como muros de bastante alzado de mampuestos de mediano tamaño trabados con arcilla y con las partes planas siempre hacia el interior, además son más gruesos que en épocas anteriores y conformaban estancias más grandes, y pavimentos en la c/Ánimas y en la Nave Municipal.

Con todos estos aportes arqueológicos se puede decir que la urbe se encontraba en la zona alta de Chiclana, en la desembocadura del río Iro según el Modelo Digital Terrestre (2014), la cual fue creciendo y ampliándose sobre los cimientos de la antigua muralla, con edificios más amplios en comparación a épocas anteriores y posiblemente dedicados al almacenamiento debido al fructífero comercio que se va desarrollando en el Mediterráneo, dando lugar a una ciudad exprofeso con un planteamiento urbanístico claro, aterrazado y con casas cuadrangulares, distribuidas entre calles empedradas con canalizaciones de agua y espacios abiertos, rodeada por una muralla cuyos muros se orientan según los ejes cardinales Noroeste-Sureste, Noreste-Suroeste.

Ya en época romana nos encontramos con yacimientos como El Corbacho Chico (Plano 2, no 25), Huerta del Rosario (Plano 2, no 21), Huerta Alta (Plano 2, no 22), Colinas de Santa Ana (Plano 2, noㅡ 23), El Carrascal (Plano 2, no 24), El Fontanar (Plano 2, no 1) o La Esparragosa (Plano 2, no 2) fuera 
del núcleo poblacional, mientras que en la propia ciudad se ha localizado elementos en c/Convento 2 y 11-13 (Plano 2, no 31), en c/Bodega 12 (Plano 2, no 27), en Cerro del Castillo (Plano 2, no 25) y en Plaza Mayor (Plano 2, no 29).

De todos ellos, tanto El Carrascal como El Fontanar presentan estructuras, en el primero una necrópolis de inhumación con sillares, tegulae y algunos restos de cerámica en superficie y en el segundo un gran complejo industrial alfarero con hornos y abundante cerámica, aunque la presencia de hornos también se constata en La Esparragosa y en c/Convento 11-13. Por otra parte, en La Mesa se documentó una importante villa romana de época imperial en la zona Noreste del yacimiento. Por el contrario, en el resto de enclaves sólo se ha documentado fragmentos de ánforas (Huerta del Rosario), algunas lápidas (Cerro del Castillo), y en deposición secundaria: sigilata clara, olla "Tipo Vegas" (c/Bodega 12) y Terra sigilata marmorata (Plaza Mayor).

Así pues se puede concluir que el periodo romano en el T.M. de Chiclana de la Frontera perdura hasta el siglo III d.C. con una gran importancia del río Iro como vía de comunicación hacia el interior de la campiña. Además, la gran cantidad de restos de hornos, tanto en la ciudad como a las afueras de ella, hace sospechar que estamos ante un gran testar dedicado a la producción anfórica, teniendo en cuenta que dicha zona se toma, según varios investigadores, como eje de la industria salazonera de la Bahía en época imperial (Lagóstena, 1996).

Por último, la ciudad de Chiclana presenta una continuación cronológica hasta la actualidad, algunos ejemplos, en cuanto a los yacimientos analizados, son los estratos correspondientes a época tardorromana en la c/Santísima Trinidad (Plano 2, no 30), de época islámica en c/Molino esquina Castillo (Plano 2, no 26) y de época moderna (s.XVII) en Plaza Mayor (Plano 2, no 29).

Pero el cauce del río Iro y su posterior bifurcación en Arroyo Salado y en Arroyo de la Cueva y la multitud de afluentes de ambos nos obliga a introducir yacimientos de otros dos términos municipales: el de Puerto Real y el de Medina Sidonia.

En el Término Municipal de Puerto Real, con el cauce del Arroyo Salado hasta el embalse del Pedroso, nos encontramos con dos enclaves adscritos a momentos neolíticos: El Cerro del Tesoro (Plano 2 , no 64) con un taller de industria pulimentada de ofitas para la confección de elementos líticos pulimentados como hachas, pulseras... y El Pedroso
- Navas de Tolosa (Plano 2, no 67) con industria lítica pulimentada. Posteriormente, para cronología del Bronce se localiza el yacimiento de Cerro de las Pilillas I (Plano 2, no 65). Aunque tanto este último yacimiento como el del Cerro del Tesoro y el enclave de Cerro de las Pilillas II (Plano 2, no 66) presentan mayor importancia en época romana con la presencia de ánforas, dolias, cerámica común y de mesa con sigilata tanto itálica como hispánica de los siglo I-II a.C. Además los asentamientos de Cerro de las Pilillas I y II presentan estratos de época medieval con la presencia de ollas, lebrillos y cazuelas.

Por su parte, el recorrido del Arroyo de la Cueva nos introduce en el Término Municipal de Medina Sidonia donde se puede encontrar el yacimiento de Palmosa Baja (Plano 2, no 38) con una concentración de industria lítica y de cerámicas a mano de cronología prehistórica, además de una necrópolis de inhumación conformada por cinco tumbas de paredes y cubierta de lajas de piedra junto a cerámica.

Relacionado con la Prehistoria Reciente se observa un aumento exponencial de enclaves entre ellos: Cerro Almarzán (Plano 2, no 32), Croquer (Plano 2, no 36), Granujales del Jurado (Plano 2, no 37), Cantera del Conde (Plano 2, no 39), Cortijo Poca Sangre (Plano 2, no 42), Cerro de los caracoles (Plano 2, no 49), La Arenosa I, II y IV (Plano 2, no 51, 52 y 54), Zurita III al VI (Plano 2, no 57 , 58, 59 y 60), Cerro del Cepillo Norte (Plano 2, no 61), Cerro del Cepillo Sur (Plano 2, no 62), Los Gambuzones (Plano 2, no 63), Cordones (plano 2, no 40), El Calerón (Plano 2, no 41), Cerro Pelado (Plano 2, no 48), Cerro del Almendral (Plano 2, no 46), Casa de máquinas (Plano 2, no 47) y Monte del Berrueco (Plano 2, no 33). A excepción de Zurita VI, donde se puede apreciar una estructura lítica de planta circular tipo dolménico y de construcciones de época moderna (s. XVII en adelante), el resto de enclaves no presentan estructuras en superficie.

La mayoría de ellos no sólo se adscriben a momentos prehistóricos sino que son poblados posteriormente en época antigua, medieval o moderna, es el caso del yacimiento Monte del Berrueco (Plano 2, no 33) donde se ha documentado abundante y variado material desde la Edad del Bronce hasta época romana republicana, o el enclave de Los Gambuzones con hallazgos adscritos a Prehistoria Reciente, época antigua (púnica, republicana y altoimperial) y época moderna. 
Así pues, yacimientos como Monte del Berrueco, El Calerón, Cortijo Poca Sangre, Cerro del Almendral, Cerro Pelado, Cerro del Cepillo Norte, Cordones, Los Gambuzones, Casa de máquinas no se pueden adscribir sólo a un período histórico.

Sin embargo, sí podemos decir que en época romana se desarrollaron enclaves nuevos como La Palmosa I y II (Plano 2, no 34 y 35), Arroyo de los Santos (Plano 2, no 44), La Arenosa III (Plano 2, no 53), Gilaila (Plano 2, no 43), Ermita de los Santos Mártires (Plano 2, no 45) y Cerro Pelado - Almeriques (Plano 2, no 50).

\section{4. ¿Coincidencia de nombres, una única vía flu- vial u otra cosa?}

En todo el territorio de la provincia de Cádiz, el repetido uso de hidrónimos relacionados con la sal (Salado, Saladillo, Saltillo...) hace indicar la importancia de esta en la zona, además de la propia configuración de estos, siendo verdaderos brazos de mar, tal y como relata R. Festo Avieno en Ora Marítima (Gavala, 1992).

La palabra "sal" proveniente de los celtas significa "salto, agua agitada" y es origen de numerosos hidrónimos, no sólo en la provincia de Cádiz ni en España, sino en toda Europa: Sal-ara > Sauldre (Francia), Salantia $>$ Salence (Suiza), Sal-erna $>$ Salerne (Italia)... Asimismo, sus aguas no eran saladas como se podría pensar en relación al término "sal" y posiblemente derivan de la palabra documentada "Salacio" > Salazo, dando lugar a Salado por asociación etimológica (Galmés, 2000).

Sin embargo, tanto el Arroyo del Salado de Caulina (Jerez de la Fra.) como el Arroyo Salado (Chiclana de la Fra.) se desarrollan por terrenos triásicos que le confieren un carácter salobre, con un alto contenido de cloruros y sulfatos, además de encontrarse estrechamente ligados a salinas que vierten sus aguas a ambas vías fluviales y por ello, la utilización frecuente del apelativo de salado (Gutiérrez Mas et al., 1991).

Así pues, la utilización de la palabra salado en diversos hidrónimos no es una mera coincidencia, sino que hace referencia al carácter salobre de los mismos por la presencia de sal, materia prima muy cotizada desde el Bronce Final.

Y es, desde estos momentos, cuando los complejos salinos se encuentran vinculados a enclaves arqueológicos estratégicos u oppida, debido al beneficio que suponía tanto para hombres como para animales a lo largo de los siglos, y por ello, es- tas salinas tendrían un carácter muy local, siendo utilizadas por las gentes de los alrededores.

No debemos olvidar que "tanto las afloraciones de aguas salobres como las lagunas y humedales salobres se encuentran en íntima relación con las vías de comunicación terrestre, tanto por las marismas de interior como por las corrientes fluviales" y que "por todas ellas pasan diversos tipos de vías pecuarias" donde "los animales necesitarían sal en su dieta como parte de la alimentación" (Valiente et al., 2017). En relación al Arroyo del Salado de Caulina destaca la salina "Las Salinillas" cercana a la confluencia de varias vías pecuarias: la Cañada Real Ancha, la Cañada Real de Cuartillos y la Cañada de Lomopardo a Albadalejo y en cuanto al Río Iro Arroyo Salado encontramos las lagunas de Jeli y Montellano, pertenecientes al Complejo Endorreico de Chiclana, en relación a la vía Cordel de los Marchantes.

Pero, y en el tránsito del IV al III milenio a.n.e., ¿qué ocurría con ambos arroyos? ¿Existía alguna conexión entre ellos y entre sus dos grandes yacimientos: "El Trobal" en Jerez de la Fra. (Plano 1, no 2) y "La Esparragosa" en Chiclana de la Fra. (Plano $2, \mathrm{n}-2)$ ?

Ambos enclaves se desarrollan en el tránsito del IV al III milenio a.n.e., momento de inicio de los primeros "campos de silos", produciéndose un cambio en la estructuración social con la manifestación de las primeras divisiones sociales, desarrollándose el germen de una jerarquización social basada en el control del territorio, donde la provincia de Cádiz actuaría como territorio productivo agrícola y ganadero (Montañés, 1998; Montañés et al., 1999; Pérez et al., 1999; Ramos, 2004).

Si bien dichas sociedades pertenecen al mismo encuadre cronológico, para poder entender la posible unión de ambas vías fluviales tenemos que entender que la geografía de la época dista mucho de la actual, por lo que es necesario consultar los estudios realizados de Oswaldo Arteaga et al. $(2008,2016)$ y/o los mapas de Juan Gavala y Laborde (1992) (Figura 13) o el trabajo de Fco. Javier Gracia Prieto (1999).

En ellos, no sólo observamos la existencia del lagus ligustinus, sino también un retroceso de las líneas de costa y de la apertura de la desembocadura del río Guadalete. Y es, sobretodo, en los mapas de Juan Gavala y Laborde (1992) donde podemos deducir que el Arroyo del Salado de Caulina 
y el Río Iro - Arroyo Salado no tenían una unión directa entre ambos, sino que confluirían en el Río Guadalete (Plano 3), teniendo en cuenta que el mapa de Juan Gavala y Laborde al que hacemos referencia corresponde a una reconstrucción geológica de época romana.

Sin embargo, Juan Gavala y Laborde fue el primer ingeniero de minas que realizó las primeras hipótesis sobre el origen de la Bahía de Cádiz, donde el Guadalete durante el Período Diluvial (Cuaternario Antiguo) debió de presentar un caudal mucho más abundante, produciendo una mayor erosión sobretodo en su desembocadura, al juntarse con la corriente de reflujo de la marea, dando lugar a un amplio estuario con límites en Rota, Sancti-Petri y El Portal y en su interior islas como Cádiz y San Fernando.

Tras la finalización de dicho período y disminuir las precipitaciones, el Guadalete deja de ser tan erosivo y se inició la sedimentación y relleno del estuario, desarrollándose la zona de esteros o marismas por donde, posteriormente, se abriría paso, prologándose por el actual cauce del Caño de Sancti-Petri hasta alcanzar el mar. Además de otros brazos como el que desembocaba en el actual Río Arillo o el que bordearía la sierra de San Cristobal desembocando en el Puerto de Santa María (Gutiérrez Mas et al., 1991).

\section{Conclusiones}

Con todo lo expuesto anteriormente, podemos decir que tanto el Arroyo del Salado de Caulina del T.M. de Jerez como el Rio Iro - Arroyo Salado del T.M. de Chiclana fueron desde época prehistórica motores importantes para la zona, pues a lo largo de todo su cauce se han localizado diversos enclaves.

El agua ha sido desde los primeros momentos de la evolución humana materia prima fundamental, al ser un elemento de la naturaleza primordial para el sostenimiento y la reproducción de la vida, siendo un componente indispensable para la subsistencia.

Es por ello que a lo largo de toda la historia, la sociedad ha recurrido a ella para generar y mantener el crecimiento económico y la prosperidad, a través de actividades tales como la agricultura, la pesca, la creación de los metales, el transporte, etc. Y por eso la localización de poblados en los márgenes de ríos, arroyos, surgencias de agua y/o las líneas de costa donde convergen los cauces de ríos y torrentes, son los biotopos necesarios e idóneos (Martínez, 2020).

Según ha evolucionado el hombre, mayor capacidad de recursos ha extraído de él, comenzando sólo por la pesca y el marisqueo en época Prehistórica, con una expropiación de la sal ya desde época Neo-

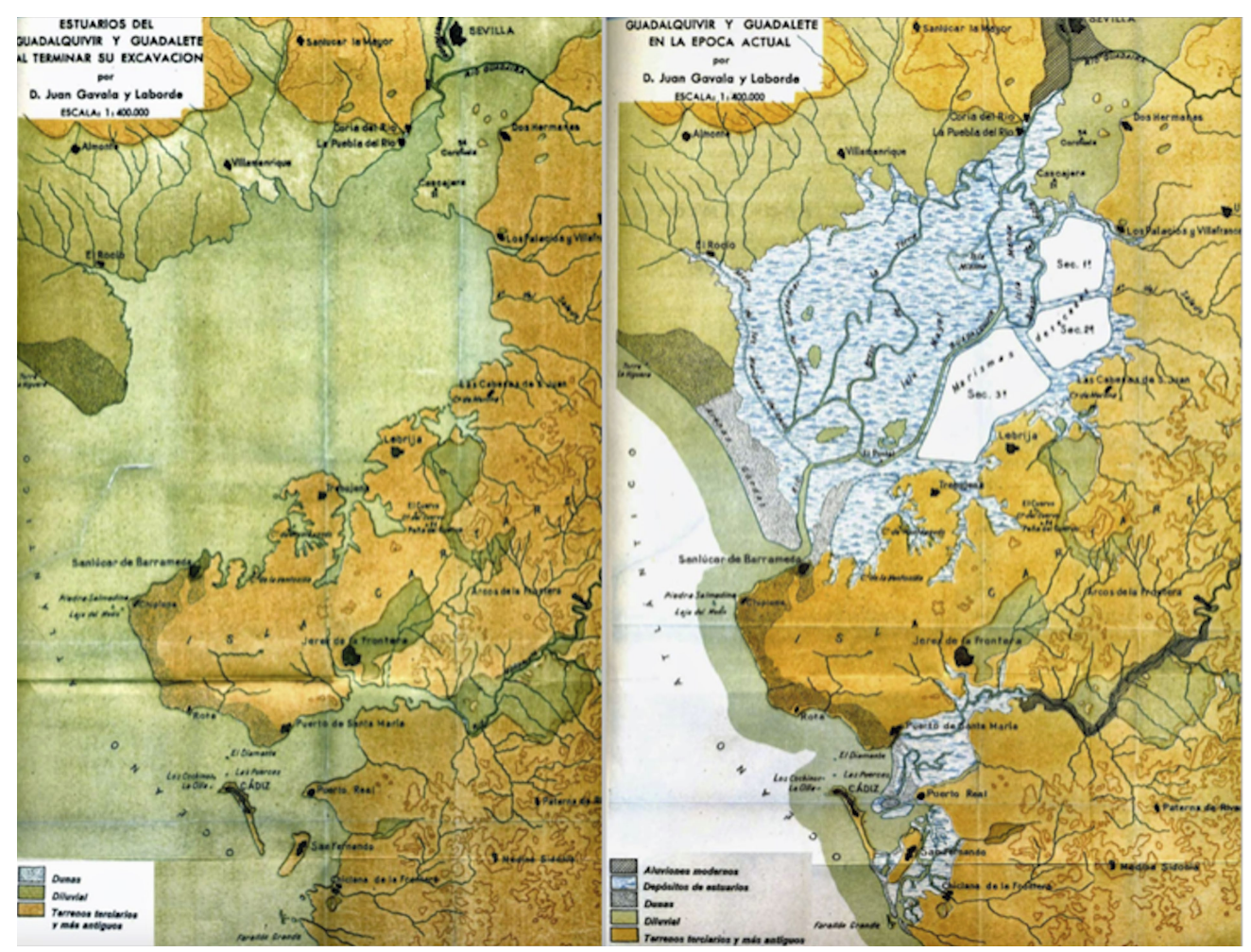

Figura 13. Mapas de Juan Gavala y Laborde (1992). 

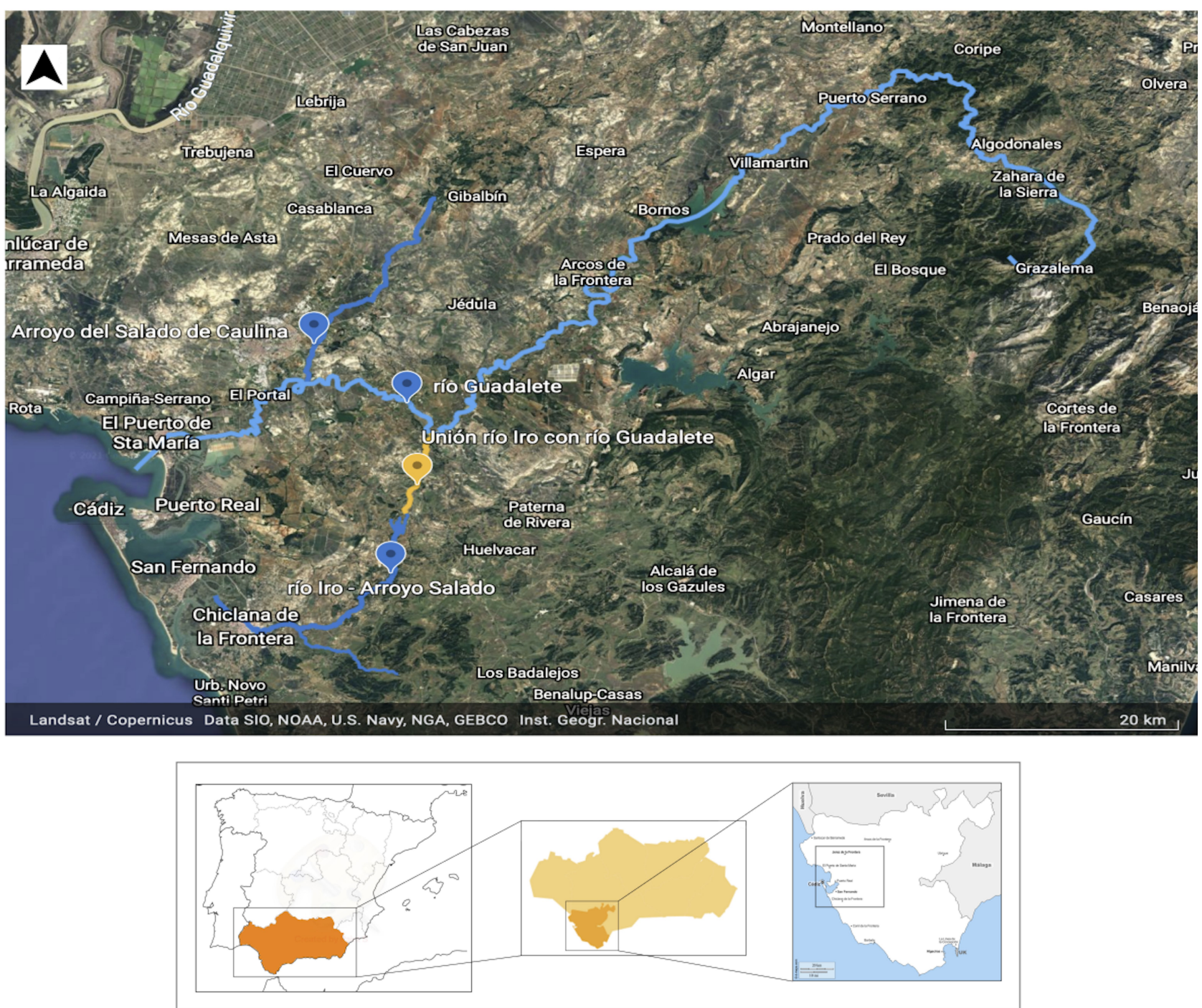

Plano 3. Unión del río Iro-Arroyo Salado (T.M. de Chiclana) y del Arroyo del Salado de Caulina (T.M. de Jerez) con el río Guadalete. (Fuente: Elaboración propia).

lítica, modificación de sus cauces o reconducción de sus aguas en época romana y posteriormente, obras de ingeniería como la creación de embalses.

Pero centrándonos en la época que nos ocupa, en el tránsito del IV al III milenio a.n.e. las sociedades humanas presentan profundos cambios económicos con la instauración de la agricultura intensiva del cereal, desarrollándose así asentamientos de gran envergadura con estructuras delimitadoras, campos de silos y artesanía especializada, como son los casos de El Trobal (González, 1987a; Cantillo, 2013; Martínez, 2018, 2021; Ruiz, 1991), La Esparragosa (Martínez, 2021; Pérez et al., 2005; Ramos et al., 2008; Vijande et al., 2018, 2019) o La Mesa (Domínguez-Bella y Ramos, 2000; Pérez et al., 1999; Ramos, 1999; Ramos et al., 1993-1994, 1998).

Con la agricultura rotatoria y de policultivo del cereal se hizo necesario un aumento del uso del agua para el regadío de esta, pues no sólo se utilizaron especies como el trigo o la cebada en relación al consumo humano sino también el mijo para los animales, las aves y cuadrúpedos (Alonso, 2000). Por lo que esta necesidad del agua provocó una explosión demográfica caracterizada en el aumento de enclaves a lo largo de todo el fértil valle del Guadalquivir y afluentes.

Por otro lado, ya desde el Neolítico Medio (4500-3500 a.n.e.) se venía produciendo la extracción de sal en la localización de Cardona (Barcelona) mediante el golpeo de bloques de halita con hachas y azuelas (Figuls et al., 2007, 2010). Posteriormente, en torno al III milenio a.n.e. se localiza el yacimiento de Las Marismillas (Sevilla), estudios de J.L. Escacena et al. (1996) lo sitúan en una zona costera, libre de pleamar, y explican el 
método de obtención de la sal mediante ignición: evaporación total del agua por la utilización del fuego en cuencos cerámicos, donde se obtendrían costras de sal.

El uso de la sal desde épocas prehistóricas no sólo va aparejado a la conservación de los alimentos: posterior consumo o distribución de alimentos, sino también como condimento alimenticio y parte de la alimentación del ganado, por lo que su extracción debió de realizarse tanto en el entorno inmediato costero como en los manantiales salinos, lagunas o arroyos salobres. De hecho, numerosos yacimientos de la zona de estudio se localizan junto a depósitos del Trías Keuper (Ramos et al., 2013).

Por último, la gran acumulación de restos malacológicos y de ictiofauna en los yacimientos determina la importancia de la pesca y del marisqueo, aparejado a un dominio de técnicas, tanto para su conservación como para su distribución, y de sistemas de navegación, como El Retamar en Puerto Real (Ramos et al., 2013; Ramos y Lazarich, 2002a, 2002b; Zabala et al., 2002, 2008) o La Esparragosa en Chiclana (Cantillo et al., 2010).

Así pues, por todo lo expuesto anteriormente, se puede afirmar que las sociedades prehistóricas del IV - III milenio a.n.e. tenían un control del medio, y por ende, la localización de los poblados en zonas altas cercanas a alguna confluencia de agua, imprescindible para todos los aspectos de la vida cotidiana de dichas sociedades, no era una mera coincidencia.

Por ello, la evolución de ambas vías fluviales se ha visto afectada por la interacción antrópica desde época prehistórica, dando lugar a una alteración del cauce y a los distintos sucesos de inundaciones.

Del río Iro se conoce que en época antigua (Figura 14), desembocaba en la actual Plaza de España donde se localiza el Puente Grande, entre dos cerros: el Cerro del Castillo donde se asentaba el poblado amurallado y La Banda, lugar de producción salina, actividades pesqueras, barrenas y alfares. A continuación, se encontraba una amplia ensenada, localizada ente el actual Pelagatos en la margen izquierda y La Carabina en la derecha, lugar donde atracaban y varaban los barcos y seguramente donde debió asentarse el puerto (Grupo Iro XXI, 2016d, 2016e).

El problema de las diversas inundaciones se debe tanto a diversas actuaciones antrópicas como a la ocupación urbana de los márgenes del río Iro.
Así pues, se acometieron grandes movimientos de tierras para construir salinas, provocando una obstaculización y una reducción de su capacidad de desagüe debido al trazado sinuoso de los esteros y al acopio de sedimento en sus márgenes. Además de la construcción del Puente de Compuertas y su desuso con la estación depuradora de aguas residuales. Por otro lado, aunque el proyecto de canalización se inicia en 1807 con el "Canal del Príncipe Almirante", el cual no se pudo llevar a término, no será hasta el siglo XX cuando se produzca una canalización para eliminar dos meandros en la zona de las salinas y, posteriormente, en 1999 se realizaron las obras de encauzamiento del río en todo el núcleo urbano, reforzando el encauzamiento existente y siendo la causa principal de las frecuentes inundaciones. Por ello:

"entre los años 1999 y 2001 se acometieron distintas obras:

- Refuerzo del encauzamiento existente mediante muros prefabricado de hormigón armado, habilitando paseos laterales en los márgenes.

- Prolongación de dicho encauzamiento hacia aguas arriba, hasta la entrada del río en el núcleo urbano, mediante muros de hormigón armado ejecutados in situ, cimentados sobre pilotes.

- Demolición del Puente de Compuertas y construcción de un nuevo puente aguas abajo del mismo, de un solo vano de $60 \mathrm{~m}$ de luz, con tablero atirantado desde dos arcos metálicos.

- Ampliación del cauce aguas abajo del nuevo puente, hasta su desembocadura en el Caño de Sancti Petri." (Muñoz et al., 2002).

Así pues, el cauce del río Iro se ha ido adecuando a las necesidades humanas. Sin embargo, actualmente, los chiclaneros y turistas consideran que el cauce urbano del río se encuentra desaprovechado, pudiendo ser un punto de revitalización económica para la ciudad con la posibilidad de una ribera de ocio y comercio, actividades náuticas e incluso hacer navegable el tramo urbano conectándolo con los caños y salinas de Sancti Petri (Aragón, 2011).

Y en cuanto al Arroyo del Salado de Caulina conocemos que se desarrolló en un territorio con aspecto de estero y de un extenso aguazal que se 


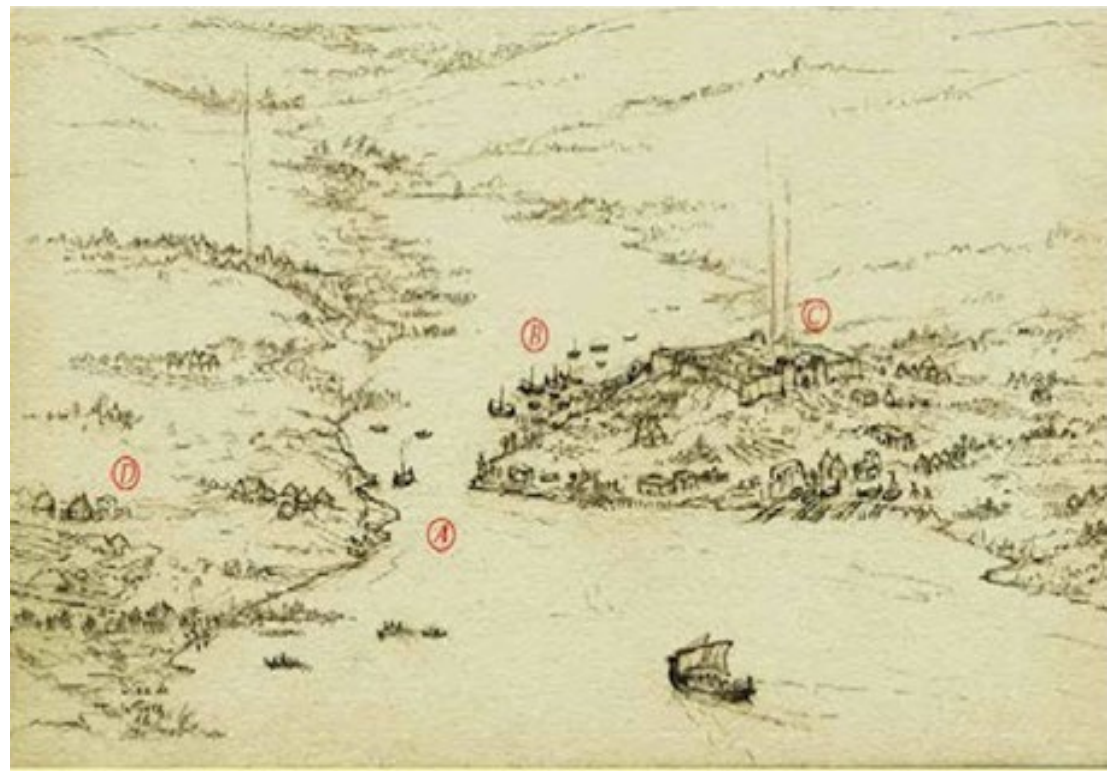

Reproducción idealizada de la Chiclana fenicia (siglos VIII-VI C), a vista de pájaro desde la vertical del actual Puente Azul.

A. Desembocadura del rio Iro (Besilo) en los dos cerros, unidos hoy por el Puente Grande.

B. Ancha ensenada entre el actual Pelagatos (margen izquierda) y La Carabina (derecha).

C. Poblado amurallado en el Cerro del Castillo. Alrededor, grupos de viviendas tartésicas.

D. En la margen derecha, hoy la Banda, aguas abajo: primeras salinas, creadas por los fenicios, activi-

dades pesqueras, viviendas tartésicas. Aguas arriba: barreros y alfares.

Figura 14. Reproducción idealizada de la Chiclana fenicia (Siglos VIII-VI a.C.), a vista de pájaro desde la vertical del actual Puente Azul. (Fuente: Grupo Iro XXI, 2016e).

anegaba en épocas invernales. Durante los siglos XVIII y XIX el cauce del arroyo se bifurcaba en dos brazos, en la zona actual de la Venta La Cueva, para unirse aguas abajo. Aunque en la actualidad desemboca en el Guadalete, hasta mediados del s. XVII se unía al río de San Pedro, ya que el Guadalete presentaba dos brazos en su estuario: uno que desembocaba en El Puerto de Santa María y otro, el Albadalejo, que se comunicaba con un canal hacia Puerto Real y denominado, posteriormente, río San Pedro (García, 2017, 2018b; González y Ruiz, 1999; López y Pérez, 2013).

En la segunda década del s. XX se realizaron obras de drenaje y canalización para evitar inundaciones en una zona destinada a cultivos, con ello se vio profundamente alterado el cauce, perdiendo su trazado meandriforme, e incluso creándose un nuevo cauce cuyas riberas artificiales se protegieron con grandes muros. Por último, en 2011, tras la gran inundación de 2010, se llevaron a cabo obras de restauración ambiental donde se retiraron lodos y sedimentos de las riberas, se cortaron numerosos eucaliptos y se recuperó la vegetación natural (álamos, tarajes y sauces). Finalmente en 2017 se retiró la antigua tubería pensando en la creación de un gran paseo que uniría Jerez con El
Puerto a través del Guadalete (Aleu, 2017; García, 2011, 2018a).

Finalmente, en relación a la hipótesis de unión entre el Arroyo del Salado de Caulina en el T.M. de Jerez y el Río Iro - Arroyo Salado del T.M. de Chiclana se puede dictaminar que no existiría una continuación sino que ambos desembocarían en el río Guadalete (plano 3), lo que no elimina la posibilidad de contacto entre los yacimientos de El Trobal (Jerez) y de La Esparragosa (Chiclana) debido al conocimiento de sistemas de navegación.

Por todo lo comentado en estas páginas podemos decir que tanto el Arroyo Salado de Caulina como el río Iro a lo largo de todo su cauce fueron ejes vertebradores de la proliferación de los diversos yacimientos citados en el apartado dos y tres. Pues debido a la tipología del suelo y al contexto medioambiental que en ellos se desarrollaba, las sociedades prehistóricas se asentaron en las riberas de estos. Repitiéndose dicho proceso a lo largo de toda la historia y por ende, modificando el paisaje a las necesidades de cada época.

\section{Bibliografía}

ABELLÁN PÉREZ, Juan. 2002: “Construcción y 
reparación de estructuras viales. Jerez de la Frontera en el siglo XV". Estudios sobre Patrimonio, Cultura y Ciencias Medievales, 3, vol. 1, pp. 7-21.

ACUÑA CAMACHO, Juan (dir.). 2009: PGOU PUERTO REAL. Ayuntamiento de Puerto Real, Gerencia Municipal de Urbanismo de Puerto Real.

ALEU C., Francisco. 2017: Un gran paseo unirá Jerez con El puerto a través del Guadalete. http:// andaluciainformacion.es/jerez/651465/ungran-paseo-unira-jerez-con-el-puerto-a-través-del-gudalete/. Consultado el 12 de octubre de 2021.

ALONSO MARTÍNEZ, Natàlia. 2000: "Cultivos y producción agrícola en época ibérica”. SAGVNTVM-PLAV: III Reunió sobre Economía en el Món Ibèric, Extra-3, pp. 25-46.

ÁLVAREZ DE SOTOMAYOR Y RUBIO, Juan María. 1824: Los doce libros de agricultura que escribió en latín Lucio Junio Moderato Columela, vol. 1 y 2 . Madrid.

ARAGÓN, Jesús. 2011: El río Iro, el nexo olvidado entre La Banda y El Lugar.http://www.lavozdigital.es/cadiz/20110926/chiclana/nexo-olvidado-entre-banda-20110926.html. Consultado el 11 de octubre de 2021.

ARTEAGA, Oswaldo; D. SCHULZ, Horst; ROOS, Ana Mà. 2008: "Geoarqueología Dialéctica en la Bahía de Cádiz". Revista Atlántica-Mediterránea de Prehistoria y Arqueología Social, 10, pp. 21-116

ARTEAGA, Oswaldo; BARRAGÁN MALLAFRET, Daniel; ROOS, Ana Ma; D. SCHULZ, Horst. 2016: "Primicia cartográfica del Río Guadalquivir hace 6500 años". Revista Atlántica-Mediterránea de Prehistoria y Arqueología Social, 18, pp. 139-161.

AUTRÁN RODRÍGUEZ, José Guillermo. 1898: Monografía de Chiclana de la Frontera: apuntes para escribir la historia de Chiclana desde los tiempos primitivos y noticias de su rica colonia de campaña fundada por el Marqués de Bertemati. Cádiz.

BOHÓRQUEZ JIMÉNEZ, Domingo. 1996: Chiclana de Frontera: Geografía, Historia, Urbanismo y Arte. Publicaciones del Sur, S.A.

BOTELLA LÓPEZ, Miguel; RUIZ RODRÍGUEZ, Luis; LARA DÁVILA, Ma ${ }^{a}$ Luisa; GARCÍA GARCÍA, Carmen. 1991: "Población eneolítica del yacimiento de El Trobal, Jerez de la Frontera. Estudio antropológico". Antropología y Paleoecología Humana, 6, pp. 17-56
BUENO SERRANO, Paloma. 2014: “Un asentamiento del Bronce Final - Hierro I en el Cerro del Castillo, Chiclana (Cádiz). Nuevos datos para la interpretación de Gadeira". En M. BOTTO (ed.): Los fenicios en la Bahía de Cádiz. Nuevas investigaciones, pp. 225-251. Collezione di studi fenici 46.

BUENO SERRANO, Paloma. 2015: "Enérgico e impetuoso: el río Iro y el origen de la ciudad". En J. C. RODRÍGUEZ (coord.): El río de la memoria. 50 años de la riada 19 de octubre de 1965, pp. 18-23. Ayuntamiento de Chiclana.

BUENO SERRANO, Paloma. 2018: Guía Didáctica. Yacimiento arqueológico "El Cerro del Castillo". Los orígenes urbanos fenicio-púnicos de la ciudad de Chiclana. Diputación de Cádiz, Fundación provincial de cultura. Cádiz.

BUENO SERRANO, Paloma. 2021: "El Cerro del Castillo, Chiclana (Cádiz, España). Un asentamiento agrícola fenicio-púnico en la campiña gaditana". En A. ROPPA; M. BOTTO y P. VAN DOMMELEN (eds.): Il Mediterraneo Occidentale dalla fase fenicia all'egemonia cartaginese. Dinamiche insediative, forme rituali e cultura materiale nel V secolo a.C., pp. 229-238. Edizioni Quasar. Roma.

CABALLERO RAGEL, Jesús. 2019: Ceri, el yacimiento romano de Gibalbín y Jerez .https://jerezenlahistoria.wordpress.com/2019/04/18/ ceri-el-yacimiento-romano-de-gibalbin-y-jerez/. Consultado el 3 de abril de 2021.

CALA HURTADO, Arantxa. 2019: La diosa Ceres se 'asoma' al Guadalete. https://www.diariodejerez.es/jerez/diosa-Ceres-asoma-Guadalete 0 1353465048.html. Consultado el 20 de abril de 2021.

CANTILLO DUARTE, Juan Jesús (2013): "Los recursos marinos en la Prehistoria reciente del entorno de Jerez de la Frontera. Análisis de su explotación y consumo". En A. SANTIAGO (coord.): Siguiendo el hilo de la historia. Nuevas líneas de investigación archivística y arqueológica, Jerez de la Frontera, pp. 69-97. La Presea de papel ediciones. Jerez de la Frontera.

CANTILLO DUARTE, Juan Jesús. 2019: "Collar de conchas de Torremelgarejo". La pieza del mes del Museo Arqueológico Municipal de Jerez. Asociación de Amigos del Museo. Jerez de la Frontera.

CANTILLO DUARTE, Juan Jesús; RAMOS MUÑOZ, José; CASIMIRO-SORIGUER ESCOFET, Milagrosa; PÉREZ RODRÍGUEZ, Manuela; VIJANDE 
VILA, Eduardo; BERNAL CASASOLA, Darío; DOMÍNGUEZ-BELLA, Salvador; ZABALA JIMÉNEZ, Cristina; HERNÁNDEZ CASAL, José; CLEMENTE CONTE, Ignacio. 2010: "La explotación de los recursos marinos por sociedades cazadoras-recolectoras-mariscadoras y tribales comunitarias en la región histórica del Estrecho de Gibraltar". Férvedes, 6, pp. 105-113.

CAÑAS, Jesús A. 2018: El castillo medieval de Melgarejo en Jerez de la Frontera sufre un derrumbe. https://elpais.com/cultura/2018/08/24/ actualidad/1535100209 044754.html. Consultado el 20 de abril de 2021.

CARRETERO POBLETE, Pedro A. 2004: "Las cillas agrícolas púnico-turdetanas de la campiña gaditana (Cádiz, España)". III Coloquio Internacional CEFYP, Las ciudades fenicio-púnicas en el Mediterráneo Occidental (Adra, Almería), pp. 187-208. Editorial Universidad de Almería, Centro de Estudios Fenicios y Púnico. Almería. CASTELLANO ROMÁN, Manuel. 2017: La Cartuja de Nuestra Señora de la Defensión en Jerez de la Frontera: un modelo digital de información para la tutela de bienes inmuebles del Patrimonio Cultural. Tesis Doctoral. Universidad de Sevilla.

CHAMORRO GUTIÉRREZ, Javier. 1991: “Campaña de flotación en el Castillo de Doña Blanca ( ${ }^{\circ}{ }^{\circ}{ }^{a} M^{\mathrm{a}}$, Cádiz). Método, Muestreo y Resultados". En P. LÓPEZ (ed.): Arqueología medioambiental a través de los macrorrestos vegetales, pp. 84-106. Madrid.

COLLANTES DE TERÁN, Francisco. 1969: "El Dolmen de Matarrubilla". En Vo Simposium de Prehistoria Peninsular, pp. 47-62. Universidad de Barcelona. Barcelona.

CUADRADO ROMAN, Alberto Manuel. 2007: "Los canales de Jerez". Revista de Historia de Jerez, 14/15, pp. 67-90.

CUADRADO ROMAN, Alberto Manuel. 2011a: El Badalac, el río perdido. https://www. diariodejerez.es/ocio/Badalac-rio-perdi-

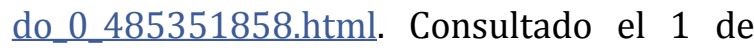
abril de 2021.

CUADRADO ROMAN, Alberto Manuel. 2011b: El 711, mil trescientos años después (y III). http:// www.entornoajerez.com/2011/05/el-711mil-trescientos-anos-despues-y.html. Consultado el 1 de abril de 2021.

DÁVILA CABAÑAS, Maㅡ José; LAGOSTENA BARRIOS, Gabriel; MATA ALMONTE, Esperanza; ZULETA ALEJANDRO, Fco. de Borja; CASTRO GARCÍA, Ma del Mar; GONZÁLEZ TORAYA, Beatriz.
2008: Carta Arqueológica Municipal de Medina Sidonia. Seminario Agustín de Horozco de Estudios Económicos de Historia Antigua y Medieval (Universidad de Cádiz), Junta de Andalucía y Excmo. Ayuntamiento de Medina Sidonia.

DOMÍNGUEZ-BELLA, Salvador; RAMOS MUÑOZ, José. 2000: "Estudio arqueométrico de las cerámicas islámicas del yacimiento de La Mesa (Chiclana de la Frontera, Cádiz, España)". En J. OLIVEIRA (coord.): III Congresso de Arqueología Peninsular. Contributos das ciencias e das tecnologias para a arqueologia da Península Ibérica, vol. 9, pp. 265-284. UTAD. Vila Real.

ESCACENA CARRASCO, José Luis; RODRÍGUEZ DE ZULOAGA MONTESINO, Mercedes; LADRÓN DE GUEVARA SÁNCHEZ, Inmaculada. 1996: Guadalquivir salobre. Elaboración prehistórica de sal marina en las antiguas bocas del río. Confederación Hidrográfica del Guadalquivir. Sevilla.

ESPINOSA, Pedro. 2008: El reñido yacimiento fenicio de Chiclana. https://elpais.com/diario/2008/06/23/andalucia/1214173330 850215.html. Consultado el 6 de junio de 2021.

ESTEVE GUERRERO, Manuel. 1956: "Una vasija de la Edad del Bronce en el Cortijo de la Torre". Noticiario Arqueológico Hispánico, III y IV, Cuadernos 1-3, p. 256. Ministerio de Educación Nacional, Dirección General de Bellas Artes. Madrid.

ESTEVE GUERRERO, Manuel. 1962: "La Torre de Melgarejo". Noticiario Arqueológico Hispánico, $V$, pp. 264-265. Ministerio de Educación Nacional, Dirección General de Bellas Artes. Madrid.

FERNÁNDEZ BARBA, Ramón. 2006: Aporte de La Mesa (Chiclana de la Frontera, Cádiz) al estudio de la cerámica islámica del Garb al Andalus. Tesina de licenciatura. Servicio de Publicaciones de la Universidad de Cádiz.

FIGULS ALONSO, Alfons; WELLER, Olivier; BONACHE ALACETE, Jorge; GONZÁLEZ HUERTAS, Joan. 2007: "El método de producción minera durante el Neolítico Medio en la "Vall Salina" de Cardona (Cataluña, España). Estudio del utillaje lítico y prácticas experimentales de explotación minera". En N. MORÈRE (ed.): Las salinas y la sal del interior en la Historia: Economía, medioambiente y sociedad, Actas del 
Congreso Internacional de Sigüenza, vol. I, pp. 73-99. Univeridad Rey Juan Carlos. Madrid.

FIGULS ALONSO, Alfons; WELLER, Olivier; GRANDIA i BORRÀS, Fidel. 2010: "La «Vall Salina» de Cardona: los orígenes de la minería de la sal gema y las transformaciones socioeconómicas en las comunidades del neolítico medio catalán". En F.J. ABARQUERO y E. GUERRA (eds.): Los yacimientos de Villafáfila (Zamora) en el marco de las explotaciones salineras de la prehistoria europea, Actas de la VII Bienal de la Restauración y Gestión del Patrimonio, pp. 4984. Consejería de Cultura y Turismo. Valladolid.

FORNELL MUÑOZ, Alejandro. 2004: "Poblamiento romano en el valle del Guadalete (Cádiz)". Florentia Iliberritana, 15, pp. 73-113.

GALMÉS DE FUENTES, Álvaro. 2000: Los topónimos: sus blasones y trofeos (La toponimia mítica). Real Academia de la Historia. Madrid.

GARCÍA LÁZARO, José; GARCÍA LÁZARO, Agustín. 2011: Obras de restauración ambiental (IV). El Salado de Caulina, un pequeño arroyo de grandes crecidas. http://www.entornoajerez. com/2011/10/obras-de-restauracion-ambiental-iv-el.html. Consultado el 1 de abril de 2021.

GARCÍA LÁZARO, José; GARCÍA LÁZARO, Agustín. 2015: Viejos puentes en viejos caminos. https://www.entornoajerez.com/search?q=Viejos+puentes+en+viejos+caminos. Consultado el 1 de abril de 2021.

GARCÍA LÁZARO, José; GARCÍA LÁZARO, Agustín. 2018a: El Salado: algo más que un arroyo (1). www.entornoajerez.com/2018/06/el-saladoalgo-mas-que-um-arroyo-1-un.html. Consultado el 12 de octubre de 2021.

GARCÍA LÁZARO, José; GARCÍA LÁZARO, Agustín. 2018b: El Salado: algo más que un arroyo (2). www.entornoajere.com/2018/06/el-saladoalgo-mas-que-un-arroyo-2-al.html. Consultado el 12 de octubre de 2021.

GARCÍA ROMERO, Fco. Antonio. 2008: El yacimiento de Gibalbín. Nuestro amigo Andrés. https://www.diariodejerez.es/opinion/articulos/yacimiento-GibalbinNuestro-amigo-Andres 0 142185922.html. Consultado el 3 de abril de 2021.

GAVALA Y LABORDE, Juan. 1992: Geología de la costa y Bahía de Cádiz y el poema "Ora Maríti$m a$ ", de Avieno. Servicio de Publicaciones de la Diputación de Cádiz. Cádiz.

GÓMEZ DÍAZ-FRANZÓN, Ana. 2012: Estella del
Marqués. Un pueblo de colonización agrícola (1954-1967) en Jerez de la Frontera (Cádiz). Amazon, edición electrónica.

GONZÁLEZ FERNÁNDEZ, Julián. 2014: "Inscripción romana del yacimiento de Gibalbín (Cádiz) con indicación de su condición de municipio". SPAL. Revista de Prehistoria y Arqueología, 23, pp. 191-196

GONZÁLEZ FUSTEGUERAS, Manuel Ángel (dir.). 2016: PGOU de Chiclana de la Frontera. Territorio y Ciudad SLP.

GONZÁLEZ RODRÍGUEZ, Rosalía. 1987a: “El yacimiento de 'El Trobal' (Jerez de la Frontera, Cádiz). Nuevas aportaciones a la cultura de los silos de la baja Andalucía". Anuario Arqueológico de Andalucía 1986. Tomo III, pp. 82-88. Junta de Andalucía. Sevilla.

GONZÁLEZ RODRÍGUEZ, Rosalía. 1987b: “Cerro Naranja. Un asentamiento rural púnico en la campiña de Jerez". Anuario Arqueológico de Andalucía de 1985. Tomo III, Actividades de Urgencia, pp. 90-95. Junta de Andalucía. Sevilla.

GONZÁLEZ RODRÍGUEZ, Rosalía. 1987c: "Notas sobre las excavaciones de urgencia realizadas en el yacimiento prerromano de Cerro Naranjo (Finca de Los Garcilasos, Jerez de la Frontera)". Cádiz en su Historia. VI Jornadas de Historia de Cádiz, pp. 27-44. Publicaciones de la Caja de Ahorros de Cádiz. Cádiz.

GONZÁLEZ RODRÍGUEZ, Rosalía. 1989: “La prospección de superficie en la zona noroccidental del término municipal de Jerez de la Frontera". Anuario Arqueológico de Andalucía. Tomo II, Actividades sistemáticas, pp. 85-88. Junta de Andalucía. Sevilla.

GONZÁLEZ RODRÍGUEZ, Rosalía; RAMOS MUÑOZ, José. 1988: "Torre Melgarejo, un sepulcro de inhumación colectiva en los Llanos de Caulina (jerez, Cádiz)". Anuario Arqueológico de Andalucía. Tomo III, Actividades de urgencia, pp. 8498. Junta de Andalucía. Sevilla.

GONZÁLEZ RODRÍGUEZ, Rosalía; RAMOS MUÑOZ, José. 1991: "Análisis funcional y material de una cabaña del Bronce Final en el poblado del Trobal (Jerez de la Frontera)". Cuadernos de Prehistoria de la Universidad de Cádiz, 1.

GONZÁLEZ RODRÍGUEZ, Rosalía y RUIZ MATA, Diego (1999): "Prehistoria e Historia Antigua de Jerez". En D. CARO (coord.): Historia de Jerez de la Frontera. Tomo I. De los orígenes a la época medieval, pp. 15-188. Diputación de Cádiz Servicio de Publicaciones. Cádiz. 
GONZÁLEZ RODRÍGUEZ, Rosalía; BARRIONUEVO CONTRERAS, Francisco; AGUILAR MOYA, Laureano; RUIZ MATA, Diego. 1993: "Proyecto: Paleografía humana del extremo noroccidental de Cádiz. Los procesos culturales desde el Neolítico a Epoca Medieval. Formas de contacto y aculturación". En J. Ma - CAMPOS y F. NOCETE (coords.): Investigaciones arqueológica en Andalucía 1985-1992: Proyectos. comunicaciones que se presentan a las VI Jornadas de Arqueología Andaluza a celebrar en Huelva, del 25 al 29 de enero de 1993, pp. 799-808. Junta de Andalucía, Consejería de Cultura y Medio Ambiente. Dirección General de Bienes Culturales. Sevilla.

GONZÁLEZ RODRÍGUEZ, Rosalía; AGUILAR MOYA, Laureano; MARTÍN MOCHALES, Domingo; BARRIONUEVO CONTRERAS, Francisco; COLLADO MORENO, Manuel. 2008: Carta Arqueológica Municipal de Jerez: El núcleo urbano. Junta de Andalucía.

GRACIA PRIETO, Fco. Javier. 1999: “Geomorfología de La Mesa y de las Terrazas del río Iro y Arroyo de la Cueva". En J. RAMOS; M. MONTAÑÉS; M. PÉREZ; V. CASTAÑEDA; N. HERRERO; Ma E. GARCÍA e I. CÁCERES (coords.): Excavaciones arqueológicas en La Mesa (Chiclana de la Frontera, Cádiz),pp. 31-39. Ayuntamiento de Chiclana, Universidad de Cádiz y Fundación Vipren.

GRUPO IRO XXI. 2016a: De la etimología del rio Iro (I). http://grupoiroxxi.blogspot. com/2016/10/de-la-etimologia-del-rio-iro-i. html. Consultado el 13 de mayo de 2021.

GRUPO IRO XXI. 2016b: De la etimología del rio Iro (II). http://grupoiroxxi.blogspot. com/2016/12/de-la-etimologia-del-rio-iro-2. html Consultado el 13 de mayo de 2021.

GRUPO IRO XXI. 2016c: El arroyo de la Cueva. http://grupoiroxxi.blogspot.com/2016/11/ el-arroyo-de-la-cueva.html. Consultado el 20 de mayo de 2021.

GRUPO IRO XXI. 2016d: De Cádiz a Chiclana por el río Iro. http://grupoiroxxi,blogspot. com/2016/03/de-cadiz-chiclana-por-el-rioiro.html. Consultado el 11 de octubre de 2021.

GRUPO IRO XXI. 2016e: Una ciudad fenicia sobre el río Iro. http://grupoiroxxi.blogspot. com/2016/03/una-ciudad-fenicia-sobre-elrio-iro.html. Consultado el 11 de octubre de 2021.

GRUPO IRO XXI. 2017: La cuenca alta del Iro: el arroyo del Salado. http://grupoiroxxi.blogs- pot.com/2017/10/la-cuenca-alta-del-iro-elarroyo-salado.html. Consultado el 20 de mayo de 2021.

GRUPO IRO XXI. 2018: ¿Qué cantidad de agua de lluvia traslada el río Iro a Chiclana? http:// grupoiroxxi.blogspot.com/2018/02/que-cantidad-de-agua-de-lluvia-traslada.html. Consultado el 20 de mayo de 2021.

GUEVARA, Fray Antonio de. 1539: "45. Letra para don Alonso de Fonseca, obispo de Burgos, presidente de Las Indias, en la cual se declara por qué los reyes de España se llaman Reyes Católicos". Epístolas Familiares. Libro primero. Valladolid.

GUTIÉRREZ, Bartolomé. 1754: Reflexión sobre la opinión admitida por el M.R.P. Mro. Fr. Enrique Flórez que nieva la identidad de Asta con Xerez de la Frontera.

GUTIERREZ MAS, José Manuel; MARTÍN ALGARRA, Agustín; DOMÍNGUEZ BELLA, Salvador; MORAL CARDONA, José Pedro. 1991: Introducción a la Geología de la provincia de Cádiz. Servicio de Publicaciones de la Universidad de Cádiz. Cádiz.

LAGÓSTENA BARRIOS, Lázaro. 1996: Alfarería romana en la Bahía de Cádiz. Publicaciones del Sur Editores. Cádiz.

LIMÓN, Manuel. 2019: Molino de la Corta (Jerez de la Frontera). https://www.prehistoriadelsur. com/2019/10/molino-de-la-corta-jerez-dela-frontera.html. Consultado el 4 de abril de 2021.

LÓPEZ ROSENDO, Ester. 2007: "El yacimiento arqueológico de Los Villares/Montealto y los orígenes tartésicos y romanos de la población de Jerez". Revista Historia de jerez, 13, pp. 9-34. LÓPEZ ROSENDO, Ester. 2009: "El yacimiento arqueológico del cerro de Montealto/Los Villares como ejemplo de asentamiento agrícola en el Ager Ceretanus". En C. EGIDO (coord.): Actas de las XV Jornadas de Historia de Jerez. El ager Ceretanus. De las leyendas a la realidad histórica, pp. 37-76. Centro de Estudios Históricos Jerezanos y Delegación de Cultura. Jerez de la Frontera.

LÓPEZ, Tomás; ZARZANA, Francisco. 1787: Mapa geográfico de los términos de Xerez de la Frontera, Tempul, Algar, sus despoblados y pueblos confinantes. Dedicado al Excmo. Señor Conde de Florida Blanca en Jerez de la Frontera (Cádiz). Mapas generales. Madrid.

MARTÍN GUTIÉRREZ, Emilio. 2003: “Análisis de la 
toponimia y aplicación al estudio del poblamiento. El alfoz de Jerez de la Frontera durante la Baja Edad Media". HID, 30, pp. 257-300.

MARTÍN GUTIÉRREZ, Emilio. 2004: La organización del Paisaje Rural durante la Baja Edad Media. El ejemplo de Jerez de la Frontera. Universidad de Sevilla y Universidad de Cádiz.

MARTÍNEZ ROMERO, Raquel. 2018: “El yacimiento de 'El Trobal' (Jerez de la Frontera, Cádiz). Pasado y presente". Takurunna: Anuario de Estudio sobre Ronda y La Serranía, 4-5, pp. 55-78.

MARTÍNEZ ROMERO, Raquel. 2021: Estudio comparativo de los modos de vida de las sociedades de la Prehistoria Reciente (milenios IV - III a.n.e.) a través de los productos líticos hallados de zonas litorales, marismas y campiñas de Jerez y Bahía de Cádiz: El Trobal y La Esparragosa. Tesis doctoral inédita. Universidad de Cádiz.

MONTAÑÉS CABALLERO, Manuel. 1998: “Aproximación al poblamiento de la sociedad tribal en la campiña sur de Cádiz". Revista Atlántica-Mediterránea de Prehistoria y Arqueología Social, I, pp. 125-146.

MONTAÑÉS CABALLERO, Manuel; PÉREZ RODRÍGUEZ, Manuela; GARCÍA PNTOJA, M. Eugenia; RAMOS MUÑOZ, José. 1999: "Las primeras sociedades campesinas. Las sociedades comunitarias y los comienzos de la jerarquización social". En J. RAMOS y M. MONTAÑ̃ÉS (eds.): Excavaciones arqueológicas en La Mesa (Chiclana de la Frontera), pp. 111-134. Ayuntamiento de Chiclana, Universidad e Cádiz y Fundación Vipren. Chiclana de la Frontera.

MONTES MOYA, Eva María. 2014: Las prácticas agrícolas en la alta Andalucía a través de los análisis carpológicos (Desde la Prehistoria Reciente al s. II d.n.e.). Tesis doctoral. Universidad de Jaén.

MORENO ARANA, Juan A. 2018: La Torre de Melgarejo. Datos para su historia. https://www.diariodejerez.es/opinion/analisis/TORRE-MELGAREJO-DATOS-HISTORIA_0_1277872458. html. Consultado el 3 de abril de 2021.

MUÑOZ PÉREZ, Juan José; DE LA CRUZ BARROSO, Juan Carlos; VALDÉS DEL FRESNO, Pedro. 2002: "Efectos de las mareas sobre las avenidas del río Iro en Chiclana de la Frontera (Cádiz)". Ingeniería Civil, 127, pp. 133-140.

PADILLA MONGE, Aurelio. 1991: "Aproximación a la economía de Asido (Medina Sidonia, Cádiz) y su comarca en época orientalizante". HABIS, 22, pp. 7-17.
PAREDES GROSSO, Juan Manuel. 1985: El jardín de las Hespérides: Los orígenes de Andalucía en los mitos y leyendas de la Antigüedad. Madrid.

PASCUAL, Manuel. 2019: "Imágenes del yacimiento arqueológico de La Corta". Redacción de Diario de Jerez. (2019): La Junta inicia los trámites para el proyecto de musealización de La Corta. https://www.diariodejerez.es/jerez/ yacimiento-Corta-musealizacion-patrimonio-andaluz 0 1395160877.html. Consultado el 20 de abril de 2021.

PÉREZ RODRÍGUEZ, Manuela; MONTAÑÉS CABALLERO, Manuel; RAMOS MUÑOZ, José; HERRERO LAPAZ, Nuria; CASTAÑEDA FERNÁNDEZ, Vicente; IGLESIAS GARCÍA, Luis; GARCÍA PANTOJA, María Eugenia. 1999: "La Mesa (Chiclana de la Frontera): contribución al estudio de las formaciones sociales en la campiña de Cádiz". Revista de Arqueología, año no 20, no 219, pp. 44-51.

PÉREZ RODRÍGUEZ, Manuela; RAMOS MUÑOZ, José; VIJANDE VILA, Eduardo; CASTAÑEDA FERNÁNDEZ, Vicente. 2005: "Informe preliminar de la excavación arqueológica de urgencia en el asentamiento prehistórico de La Esparragosa (Chiclana de la Frontera, Cádiz)". Anuario Arqueológico de Andalucía 2002, vol. 3. Tomo 1, pp. 93-103. Junta de Andalucía. Sevilla.

PORTILLO, Joaquín. 1839: Noches jerezanas o sea la historia y descripción de la M. N. y M. L. ciudad de Jerez de la Frontera, y de su término. Tomo Primero. Jerez de la Frontera.

RAMOS MUÑOZ, José. 1991: "Las industrias líticas del Bronce Final en Jerez. Renovación metodológica y perspectivas económicas de estudio". Páginas. Revista de Humanidades, 8, pp. 238-262.

RAMOS MUÑOZ, José. 1999: Excavaciones arqueológicas en La Mesa (Chiclana de la Frontera, Cádiz): campaña de 1998, aproximación al estudio del proceso histórico de su ocupación. Ayuntamiento de Chiclana de la Frontera.

RAMOS MUÑOZ, José. 2004: "Las últimas comunidades cazadoras, recolectora y pescadoras en el Suroeste peninsular. Problemas y perspectivas del 'tránsito Epipaleolítico-Neolítico' con relación a la definición del cambio histórico. Un análisis desde el modo de producción". Sociedades recolectoras y primeros productores, pp. 71-89.

RAMOS MUÑOZ, José. 2014-15: “La Alabarda de 
Sílex de Torremelgarejo en el contexto de las sociedades de la Prehistoria Reciente de las sierras y campiñas de Cádiz". Takurunna: Takurunna: Anuario de Estudios sobre Ronda y La Serranía, 4-5, pp. 79-106.

RAMOS MUÑOZ, José. 2017: "Alabarda de sílex de Torremelgarejo". La pieza del mes del Museo Arqueológico Municipal de Jerez. Asociación de Amigos del Museo. Jerez de la Frontera.

RAMOS MUÑOZ, José; GONZÁLEZ RODRÍGUEZ, Rosalía. 1992: "Prospección arqueológica superficial en el término municipal de Jerez de la Frontera, Cádiz. Campaña de 1990". Anuario Arqueológico de Andalucía. Tomo II, pp. 64-75. Junta de Andalucía. Sevilla.

RAMOS MUÑOZ, José; CASTAÑEDA FERNÁNDEZ, Vicente; PÉREZ RODRÍGUEZ, Manuela; LAZARICH GONZÁLEZ, María; MONTAÑÉS CABALLERO, Manuel; LOZANO MOYA, José Manuel ; MARTÍNEZ PECES, Cristina. 1993: "Informe de la campaña de prospecciones arqueológicas de 1993 en el Término Municipal de Chiclana de Frontera. Una contribución al estudio del proceso de ocupación de la Banda atlántica de Cádiz durante la prehistoria". Anuario Arqueológico de Andalucía. Actividades sistemáticas, informes y memorias. Tomo II, pp. 24-34. Junta de Andalucía. Sevilla.

RAMOS MUÑOZ, José; CASTAÑEDA FERNÁNDEZ, Vicente; LAZARICH GONZÁLEZ, María; MARTÍNEZ, C.; MONTAÑÉS CABALLERO, Manuel; LOZANO MOYA, José Manuel. 1993-1994: “La secuencia prehistórica del poblado de La Mesa (Chiclana de la Frontera). Su contribución a la ordenación del territorio de la campiña litoral y banda atlántica". Boletín del Museo de Cádiz, VI, pp. 23-41.

RAMOS MUÑOZ, José; MONTAÑEZ CABALLERO, Manuel; PÉREZ RODRÍGUEZ, Manuela; DOMÍNGUEZ-BELLA, Salvador; CASTAÑEDA FERNÁNDEZ, Vicente; GARCÍA PANTOJA, Maㅡ Eugenia; HERRERO LAPAZ, Nuria; IGLESIAS GARCÍA, Luis; GRACIA PRIETO, Javier; CÁCERES SÁNCHEZ, Isabel; JURADO FRESNADILLO, Gemma; BAÑOS POZO, Carmen; BEJARANO GUEIMÚNDEZ, Diego. 1998: "Informe preliminar de la campaña de excavaciones arqueológicas de urgencia en La Mesa (Chiclana de la Frontera). Contribución al estudio de formaciones sociales en transición". Anuario Arqueológico de Andalucía, Tomo III, Vol. 1, pp. 32-54. Junta de Andalucía. Sevilla.
RAMOS MUÑOZ, José; LAZARICH GONZÁLEZ, María. 2002a: El asentamiento de 'El Retamar (Puerto Real, Cádiz). Contribución al estudio de la formación social tribal y a los inicios de la economía de producción en la Bahía de Cádiz. Universidad de Cádiz y Ayuntamiento de Puerto Real.

RAMOS MUÑOZ, José; LAZARICH GONZÁLEZ, María. 2002b: Memoria de la excavación arqueológica en el asentamiento del VI ${ }^{o}$ milenio a.n.e. de 'El Retamar' (Puerto Real, Cádiz). Arqueología Monográfica, Consejería de Cultura de la Junta de Andalucía.

RAMOS MUÑOZ, José; PÉREZ RODRÍGUEZ, Manuela; VIJANDE VILA, Eduardo; CANTILLO DUARTE, Juan Jesús; MONTAÑÉS CABALLERO, Manuel; PÉREZ RAMOS, Luis. 2008: "Los registros arqueológicos. Las prospecciones y los yacimientos documentados". En J. RAMOS (coord.): Memoria del proyecto de investigación: La ocupación prehistórica de la campiña litoral y Banda atlántica de Cádiz. Aproximación al estudio de las sociedades cazadoras-recolectoras, tribales-comunitarias y clasistas iniciales, pp. 69-126. Junta de Andalucía. Sevilla.

RAMOS MUÑOZ, José; PÉREZ RODRÍGUEZ, Manuela; CLEMENTE CONTE, Ignacio; GARCÍA DÍAZ, Virginia; RUIZ ZAPATA, Mํo Blanca; GIL GARCÍA, Ma José; VIJANDE VILA, Eduardo; CASIMIRO-SORIGUER, Milagrosa; HERNANDO CASAL, J. Antonio; ZABALA JIMÉNEZ, Cristina (2008): "La Esparragosa (Chiclana de la Frontera): un asentamiento con campo de silos en la campiña de Cádiz, del IV milenio a.n.e.". En M.S. HERNÁNDEZ; J.A. SOLER y J.A. LÓPEZ (coords.): IV Congreso del Neolítico Peninsular, vol. 1, pp. 385-392. MARQ. Alicante.

RAMOS MUÑOZ, José; DOMÍNGUEZ-BELLA, Salvador; CANTILLO DUARTE, Juan Jesús; VIJANDE VILA, Eduardo; PÉREZ RODRÍGUEZ, Manuela. 2013: "Novedades en el conocimiento de las sociedades tribales neolíticas en la banda atlántica de Cádiz. Explotación de recursos marinos e hipótesis del uso de la sal". En J. SOARES (ed.): Prè-história das Zonas Húmidas. Paisagens de Sal. Setúbal Arqueológica, vol. 14, pp. 85-112. SIMARSUL. Setúbal.

REDACCIÓN DE DIARIO DE JEREZ. 2019a: La Junta inicia los trámites para el proyecto de musealización de La Corta. https://www.diariodejerez.es/jerez/yacimiento-Corta-musealizacion-patrimonio-andaluz 01395160877. 
html. Consultado el 20 de abril de 2021.

REDACCIÓN DE DIARIO DE JEREZ. 2019b: Hallan restos de un molino de época romana en un yacimiento de La Corta. https://www.diariodejerez.es/ocio/Hallan-restos-molino-yacimiento-Corta_0_1342966063.html. Consultado el 20 de abril de 2021.

ROMERO MONTALBÁN, Jesús. 2015: “El Iro, su entorno y riadas en la Edad Media". En J.C. RODRÍGUEZ (coord.): El río de la memoria. 50 años de la riada 19 de octubre de 1965, pp. 2431. Ayuntamiento de Chiclana. Chiclana de la Frontera.

RUIZ RODRÍGUEZ, Luis; LARA DÁVILA, María Luisa; BOTELLA LÓPEZ, Miguel Cecilio; GARCÍA GARCÍA, Carmen. 1991: "Población eneolítica del yacimiento de El Trobal, Jerez de la Frontera. Estudio antropológico". Antropología y Paleontología humana, 6, pp. 17-56.

SÁNCHEZ MÚGICA, Paco. 2016: 10 paradas obligatorias en la ruta del patrimonio protegido. https://www.lavozdelsur.es/cultura/10-paradas-obligadas-en-la-ruta-del-patrimonio-protegido_20520_102.html. Consultado el 3 de abril de 2021.

SÁNCHEZ MÚGICA, Paco. 2019: Los molinos de La Corta, la escombrera que ocultaba un tesoro "excepcional" con 2.000 años de historia. https:// www.lavozdelsur.es/actualidad/sociedad/ los-molinos-de-la-corta-la-escombrera-queocultaba-un-tesoro-excepcional-con-2-000anos-de-historia 129569 102/129556.html. Consultado el 15 de abril de 2021.

SEMINARIO AGUSTÍN DE HOROZCO. 2014: Modelo digital del terreno del Cerro del Castillo y su entorno en época fenicia. Impresión digital. Realizado para la tesis de Licenciatura titulada El poblamiento colonial fenicio arcaico en la Península Ibérica: Análisis desde el yacimiento arqueológico del Cerro del Castillo, Chiclana (Cádiz). Departamento de Historia Antigua de la UCA, Universidad de Cádiz. Cádiz.

VALIENTE CÁNOVAS, Santiago; GILES PACHECO, Francisco; GUTIÉRREZ LÓPEZ, José María; REINOSO DEL RIO, Ma Cristina; GILES GUZMÁN, Francisco. 2017: "Humedales salobres como fuente de extracción de sal en Jerez de la Frontera y su entorno: Cortijo de Salinillas y "Las Salinillas" de Estella del Marqués". En O. PUCHE; M. AYARZAGÜENA; J.F. LÓPEZ y J. POUS DE LA FLOR (eds.): Minería y Metalur- gias Históricas en el sudoeste Europeo. Nuestras raíces mineras, pp. 173-185. Sociedad Española para la defensa del Patrimonio Geológico y Minero, Madrid. Madrid.

VIJANDE VILA, Eduardo. 2006: "Aproximación al conocimiento de las formaciones sociales tribales en Chiclana de la Frontera y su contribución al estudio de las mismas en el ámbito de la Banda atlántica gaditana". Revista Atlántica-Mediterránea de Prehistoria y Arqueología Social, 8, pp. 87-108

VIJANDE VILA, Eduardo; RAMOS MUÑOZ, José; FERNÁNDEZ SÁNCHEZ, Diego; CANTILLO DUARTE, Juan Jesús; PÉREZ RODRÍGUEZ, Manuela. 2019: La Esparragosa (Chiclana de la Frontera, Cádiz). Un campo de silos neolítico del IV milenio a.n.e. Consejería de Cultura y Patrimonio Histórico de la Junta de Andalucía. Sevilla.

VIJANDE VILA, Eduardo; RAMOS MUÑOZ, José; PÉREZ RODRÍGUEZ, Manuela; MORENO MÁRQUEZ, Adolfo; CANTILLO DUARTE, Juan Jesús; DOMÍNGUEZ-BELLA, Salvador; ALMISAS CRUZ, Sergio; RIQUELME CANTAL, J. Antonio; CASIMIRO-SORIGUER, Milagrosa; CLEMENTE CONTE, Ignacio; GARCÍA, Virginia; BARRENA TOCINO, Antonio; RUIZ, Blanca; GIL, Ma José; FERNÁNDEZ SÁNCHEZ, Diego Salvador. 2018: "Estudio interdisciplinar de la tumba AV del asentamiento neolítico de La Esparragosa (Chiclana de la Frontera, Cádiz, España)". Arqueología Iberoamericana, año 10, 37, pp. 40-47.

ZABALA JIMÉNEZ, Cristina; HERNANDO CASAL, José Antonio; CASIMIRO SORIGUER, Milagrosa. 2002: "Características biológicas de la fauna marina del yacimiento de 'El Retamar"'. En J. RAMOS y Ma LAZARICH (eds.): El asentamiento de "El Retamar" (Puerto Real, Cádiz)., pp. 193-204. Universidad de Cádiz y Ayuntamiento de Puerto Real. 